University of Nebraska - Lincoln

DigitalCommons@University of Nebraska - Lincoln

1993

\title{
Chromium and Reactive Element Modified Aluminide Diffusion Coatings on Superalloys: Environmental Testing
}

Robert Bianco

The Ohio State University

Robert A. Rapp

The Ohio State University

James L. Smialek

NASA Glenn Research Center, james.l.smialek@nasa.gov

Follow this and additional works at: http://digitalcommons.unl.edu/nasapub

Bianco, Robert; Rapp, Robert A.; and Smialek, James L., "Chromium and Reactive Element Modified Aluminide Diffusion Coatings on Superalloys: Environmental Testing" (1993). NASA Publications. 231.

http://digitalcommons.unl.edu/nasapub/231

This Article is brought to you for free and open access by the National Aeronautics and Space Administration at DigitalCommons@University of Nebraska - Lincoln. It has been accepted for inclusion in NASA Publications by an authorized administrator of DigitalCommons@University of Nebraska - Lincoln. 


\title{
Chromium and Reactive Element Modified Aluminide Diffusion Coatings on Superalloys: Environmental Testing
}

\author{
Robert Bianco* and Robert A. Rapp** \\ Department of Materials Science and Engineering, The Ohio State University, Columbus, Ohio 43210
}

James L. Smialek

National Aeronautics and Space Administration, Lewis Research Center, Cleveland, Ohio 44135

\begin{abstract}
The isothermal oxidation of reactive element (RE)-doped aluminide coatings on IN $713 \mathrm{LC}$ alloy substrates at $1100^{\circ} \mathrm{C}$ in air formed a continuous slow-growing $\alpha-\mathrm{Al}_{2} \mathrm{O}_{3}$ scale after $44 \mathrm{~h}$ of exposure. $\mathrm{RE}$-free (reactive element-free) aluminide coatings were characterized by a cracked oxide scale which exposed an underlying voided coating surface. The cyclic oxidation behavior of $\mathrm{Cr} / \mathrm{RE}$-modified aluminide diffusion coatings on René 80 and IN 713LC alloy substrates, and of RE-doped aluminide coatings on IN $713 \mathrm{LC}$ alloy substrates, at $1100^{\circ} \mathrm{C}$ in static air was determined. Coatings deposited by the above pack (AP) arrangement, as opposed to the powder contacting (PC) arrangement, showed improved resistance to cyclic oxidation attack. $\mathrm{RE}$-doped and $\mathrm{Cr} / \mathrm{RE}$-modified aluminide coatings exhibited considerably more adherent protective $\mathrm{Al}_{2} \mathrm{O}_{3}$ scales compared to undoped aluminide coatings. The hot corrosion behavior of $\mathrm{Cr} / \mathrm{RE}$-modified aluminide coatings on René 80 and Mar-M247 alloy substrates at $900^{\circ} \mathrm{C}$ in a $0.1 \% \mathrm{SO}_{2} / \mathrm{O}_{2}$ gas mixture also was determined. The $\mathrm{Cr} / \mathrm{RE}$-modified aluminide coatings provided better resistance to hot corrosion attack (i.e., thin film studies) than a commercial low activity aluminide coating. Coating lifetimes were strongly dependent on the chromium surface composition, since a mixed ( $\mathrm{Al}, \mathrm{Cr})_{2} \mathrm{O}_{3}$ scale better resists attack by the molten salt.
\end{abstract}

In service, diffusion aluminide coatings are exposed to aggressive environments and applied stresses at high temperatures and suffer both mechanical and chemical degradation. The intermetallic compound of aluminide coatings can be the weak link in the fatigue resistance and fracture toughness of the coating/component couple. ${ }^{1}$ Also, low activity coatings, which form by outward diffusional growth, have a tendency to embed pack powder particles into their external layer. ${ }^{2}$ These indigenous inclusions can reduce the fatigue resistance of the coating/component even further.

Aluminide diffusion coatings for use in gas turbines suffer from three forms of chemical degradation: (i) interdiffusion, (ii) oxidation, and (iii) fused salt (hot corrosion) attack. Interdiffusion and hot corrosion indirectly affect the surface or coating composition, thereby reducing the oxidation resistance of the coated component.

Interdiffusion.-Smialek and Lowell ${ }^{3}$ studied the effect of interdiffusion on the degradation of aluminide diffusion coatings on IN 100 and Mar-M200 commercial Ni-base alloys which were vacuum-annealed for $300 \mathrm{~h}$ at $1100^{\circ} \mathrm{C}$. The coatings thickened, and the Al concentration at the surface decreased, changes attributed to interdiffusion of the coating components with the substrate. In addition, carbides within the interdiffusion zone began to dissociate while others coarsened with time, thereby reducing the integrity of the interdiffusion zone. Stable carbides aligned parallel to the surface may block interdiffusion degradation. For example, Mar-M200 alloys (which contain $12 \% \mathrm{~W}, 1 \% \mathrm{Nb}$, and $0.15 \%$ C) formed a chain of blocky carbides and did not suffer any significant interdiffusion degradation, whereas IN 100 alloys (which contain only $3 \% \mathrm{Mo}, 5 \% \mathrm{Ti}$, and $0.18 \%$ C) formed more sporadic carbides and did suffer more severe interdiffusion degradation. Such prediffused coatings on IN 100 alloys suffered severe reductions in coating lifetimes upon cyclic oxidation in static air at $1100^{\circ} \mathrm{C} .^{3}$ For these hyperstoichiometric (Al-rich) $\beta$-NiAl compounds, ${ }^{4}$ depletion of $\mathrm{All}$ both resulting from the growth of $\mathrm{Al}_{2} \mathrm{O}_{3}$ scales and interdiffusion with the substrate leads to an eventual failure (i.e., the inability to form a protective $\mathrm{Al}_{2} \mathrm{O}_{3}$ scale). Low activity coatings, consisting of a hypostoichiometric (Ni-rich) $\beta-\mathrm{NiAl}$, where $\mathrm{Ni}$ is the dominant

* Electrochemical Society Student Member.

** Electrochemical Society Active Member. diffusing element, may not be so susceptible to interdiffusion degradation. ${ }^{4}$

Oxidation. - The oxidation behavior of Ni-Al alloys has been investigated widely. ${ }^{5-11}$ Pettit ${ }^{5}$ studied the oxidation behavior of a series of Ni-Al alloys [Ni-3 to 25 weight percent (w/o) Al] between 900 and $1300^{\circ} \mathrm{C}$ in $0.1 \mathrm{~atm}$ oxygen. Alloys with greater than $17 \mathrm{w} / \mathrm{o} \mathrm{Al}$ [or 32 atomic percent (a/o)] exhibited the best oxidation behavior, i.e., parabolic kinetics limited by the growth of an external $\mathrm{Al}_{2} \mathrm{O}_{3}$ scale. Hindam and Smeltzer ${ }^{6}$ studied the oxidation behavior of $\beta-\mathrm{NiAl}\left(\mathrm{Ni}-32 \mathrm{w} / \mathrm{o}\right.$ or $50 \mathrm{a} / \mathrm{o} \mathrm{Al}$ ) between 1000 and $1300^{\circ} \mathrm{C}$ in pure $\mathrm{O}_{2}$. Slow parabolic kinetics resulted from the growth of a ridged external $\alpha-\mathrm{Al}_{2} \mathrm{O}_{3}$ scale after $30 \mathrm{~min}$ exposure. Oxide spalling or loss of adherence upon furnace cooling was attributed to the formation of interfacial voids during oxide growth.

The mechanism of $\mathrm{Al}_{2} \mathrm{O}_{3}$ growth on $\beta-\mathrm{NiAl}$ is widely debated. Hindam and Smeltzer ${ }^{6}$ used inert platinum markers to determine that $\mathrm{Al}_{2} \mathrm{O}_{3}$ growth on undoped $\beta-\mathrm{NiAl}$ is controlled by inward oxygen diffusion. However, the ridged scale morphology often is ascribed to Al outdiffusion via short-circuit paths, such as grain boundaries. Prescott et al. ${ }^{7}$ confirmed that oxide grain boundaries are short-circuit paths for Al diffusion during alumina growth on $\beta$-NiAl. Young and de $\mathrm{Wit}^{8}$ used a two-stage, ${ }^{16} \mathrm{O}_{2}$ and then ${ }^{18} \mathrm{O}_{2}$, oxidation treatment with secondary ion mass spectroscopy (SIMS) analysis to determine the $\mathrm{Al}_{2} \mathrm{O}_{3}$ growth mechanism on $\beta$-NiAl compounds. Outward $\mathrm{Al}_{2} \mathrm{O}_{3}$ growth involving cation diffusion occurred at $1000^{\circ} \mathrm{C}$ on undoped and slightly $\mathrm{Y}$-doped NiAl compounds. NiAl compounds doped with $0.5 \mathrm{w} / \mathrm{O} \mathrm{Y}$ or more exhibited $\mathrm{Al}_{2} \mathrm{O}_{3}$ growth controlled by anion indiffusion.

In the transient oxidation of $\beta-\mathrm{NiAl}, \mathrm{NiAl}_{2} \mathrm{O}_{4}$ spinel, $\gamma$ $\mathrm{Al}_{2} \mathrm{O}_{3}$, and $\theta-\mathrm{Al}_{2} \mathrm{O}_{3}$ were detected by transmission electron microscopy (TEM) ${ }^{9,10}$ With increasing time, transformation of the metastable $\mathrm{Al}_{2} \mathrm{O}_{3}$ phases (whiskers) into $\alpha-\mathrm{Al}_{2} \mathrm{O}_{3}$ (ridges) occurred at the scale/gas interface and proceeded inward. Metastable $\mathrm{Al}_{2} \mathrm{O}_{3}$ phases have faster oxidation rates compared to the more protective $\alpha-\mathrm{Al}_{2} \mathrm{O}_{3}$ phase; however, the addition of a reactive element (e.g., Zr, Hf, Y), or significant $\mathrm{Cr}$, facilitates the formation of the slower-growing, more protective $\alpha-\mathrm{Al}_{2} \mathrm{O}_{3}$ scale. ${ }^{11,12}$

The oxidation behavior of coatings with an external $\beta$ $\mathrm{NiAl}$ layer also has been investigated. ${ }^{13-15}$ Both low and 
high activity coatings exhibit excellent oxidation resistance. However, after about $100 \mathrm{~h}$ of exposure at $1200^{\circ} \mathrm{C}$, the oxidation resistance drops considerably. Degradation of aluminide coatings occurs because of the selective depletion or consumption of $\mathrm{Al}$ from the coating, by the repetitive formation and spalling of protective $\mathrm{Al}_{2} \mathrm{O}_{3}$ scales and/ or interdiffusion. Eventually, the reduced $\mathrm{Al}$ surface concentration is insufficient to support the formation of a protective $\mathrm{Al}_{2} \mathrm{O}_{3}$ scale, and less protective nonadherent $\mathrm{NiAl}_{2} \mathrm{O}_{4}$ and $\mathrm{NiO}$ scales form.

The degradation of aluminide coatings can be reduced if the adherence of protective $\mathrm{Al}_{2} \mathrm{O}_{3}$ scales is improved, e.g., reducing $\mathrm{Al}$ interdiffusion losses or reducing the oxidation rate. In particular, small additions of REs (e.g., Y, Zr, Hf) considerably improve the adherence of thermally grown $\mathrm{Al}_{2} \mathrm{O}_{3}$ scales on bulk $\beta-\mathrm{NiAl}$ compounds. ${ }^{16-20}$ Recently, Bianco and Rapp ${ }^{2}$ developed a RE-doped aluminide diffusion coating via the pack cementation process, which is expected to provide the same beneficial result.

Fused salt attack (hot corrosion).-Hot corrosion is an important mode of material degradation in marine and industrial gas turbines, and it may occur in aircraft engines. Hot corrosion is the accelerated attack of a metallic component resulting from the presence of a condensed fused salt film (e.g., $\mathrm{Na}_{2} \mathrm{SO}_{4}, \mathrm{NaVO}_{3}, \mathrm{NaCl}$ ) in an oxidizing environment. The sulfation of $\mathrm{NaCl}$ vapor, introduced as an impurity either in the fuel or the ingested air, reacts with the oxides of sulfur from the combustion products of the fuel to form $\mathrm{Na}_{2} \mathrm{SO}_{4}{ }^{21}$ When the vapor pressure of $\mathrm{Na}_{2} \mathrm{SO}_{4}$ exceeds its dew point for given service conditions, condensation of a fused salt on the cooler turbine components may lead to passive or locally active attack of the surface. ${ }^{21-29}$

For resistance to hot corrosion, an alloy or coating must form a slow-growing and dense protective oxide scale with limited solubility in $\mathrm{Na}_{2} \mathrm{SO}_{4}$. Determinations of the solubilities of several oxides in pure $\mathrm{Na}_{2} \mathrm{SO}_{4}$ have shown that $\mathrm{Cr}_{2} \mathrm{O}_{3}$ and $\mathrm{Al}_{2} \mathrm{O}_{3}$ are acidic oxides because their solubility minima occur at very high acidity. ${ }^{30}$ Hence, these oxides promise better resistance to acidic salts than more basic oxides such as $\mathrm{Fe}_{2} \mathrm{O}_{3}, \mathrm{NiO}$, or $\mathrm{CoO}$. Silicon dioxide has no ionic acidic solute and therefore is not attacked by an acidic melt. ${ }^{31}$

Aluminide diffusion coatings produce a steady-state $\alpha-$ $\mathrm{Al}_{2} \mathrm{O}_{3}$ scale which does not provide adequate hot corrosion resistance. McCarron et al. ${ }^{32}$ determined experimentally that $\mathrm{Cr}$ additions $(\sim 8 \mathrm{a} / \mathrm{o})$ in bulk $\beta-\mathrm{NiAl}$ improved burner rig hot corrosion performance considerably. An aluminide diffusion coating modified with $\mathrm{Cr}$ also exhibited excellent resistance to hot corrosion attack, so modification of the surface composition by $\mathrm{Cr}$ enrichment is required to produce a more protective scale. ${ }^{33}$

Our investigation determined the high temperature performance of $\mathrm{RE}$-doped and $\mathrm{Cr} / \mathrm{RE}$-modified aluminide diffusion coatings (described in the preceding paper) on commercial Ni-base alloy substrates (e.g., IN 713LC and René 80). The isothermal and cyclic oxidation behavior at $1100^{\circ} \mathrm{C}$ in air of these coatings was determined, and the hot corrosion (thin film) resistance of $\mathrm{Cr} / \mathrm{RE}$-modified aluminide coatings at $900^{\circ} \mathrm{C}$ in $0.1 \% \mathrm{SO}_{2} / \mathrm{O}_{2}$ also was determined. The mechanisms of coating degradation are discussed.

\section{Experimental Procedures}

The experimental procedures and surface composition results for the $\mathrm{RE}$-doped and $\mathrm{Cr} / \mathrm{RE}$-modified aluminide diffusion coatings have been presented previously. ${ }^{2,35}$ Samples coated by both the $\mathrm{PC}$ and the $\mathrm{AP}$ arrangements were evaluated.

Oxidation. - The high temperature oxidation behavior of the coatings was determined by both isothermal and cyclic oxidation tests. Isothermal oxidation rates at $1100^{\circ} \mathrm{C}$ in air $\left(0.21 \mathrm{~atm} \mathrm{O}_{2}\right)$ at a flow rate of $0.1 \mathrm{liter} / \mathrm{min}$ STP were measured using a Cahn TG-171 automated thermogravimetric analyzer (TGA) equipped with the Cahn DACS plus software. Specimens were placed in an alumina crucible which was suspended from the microbalance by a sapphire wire. Parabolic rate constants were calculated from the weight-change data.

Cyclic oxidation at $1100^{\circ} \mathrm{C}$ in static air was performed at the NASA Lewis Research Center. Two specimens each were placed in six $\mathrm{FeCrAl}$ crucibles suspended by a platinum wire and separated with an alumina spacer. Specimens were lowered pneumatically and retracted from the hot zone after a $1 \mathrm{~h}$ exposure followed by a $20 \mathrm{~min}$ cool to ambient temperature. Specimens were removed periodically to be weighed and inspected. Screening tests for up to $2001 \mathrm{~h}$ cycles were conducted. Resistant coatings were evaluated further for up to $5001 \mathrm{~h}$ cycles. X-ray diffraction (XRD) analysis was used to identify the oxide and coating phases present. In addition, a Hitachi S-510 scanning electron microscope (SEM). was used to observe the oxide morphology, and electron microprobe analysis (EPMA) was used to characterize the compositions of the oxidized coating surfaces. Other specimens were mounted in epoxy, sectioned, and polished metallographically through $0.3 \mu \mathrm{m}$ alumina. These cross sections were analyzed by EPMA to determine compositional and morphological changes in the coating.

Hot corrosion studies.-The hot corrosion behavior of the coatings was determined using isothermal thin film tests. Thin films of $\mathrm{Na}_{2} \mathrm{SO}_{4}$ were applied by heating coupons to about $200^{\circ} \mathrm{C}$ on a hot plate and applying an aqueous solution from an airbrush to generate a salt coating of $5 \pm$ $1.5 \mathrm{mg} \mathrm{Na} \mathrm{NO}_{4} / \mathrm{cm}^{2}$. Coated specimens were placed in an alumina boat which was inserted into a horizontal tube furnace at $900^{\circ} \mathrm{C}$ and exposed to a Pt-catalyzed $0.1 \% \mathrm{SO}_{2} /$ $\mathrm{O}_{2}$ mixture at a flow rate of 0.1 liter/min STP. Specimens were removed periodically to be weighed, inspected, and recoated with salt. X-ray diffraction analysis was used to determine the crystalline corrosion products. Cross sections were prepared by sputtering a layer of $\mathrm{Au} / \mathrm{Pd}$ and then electroplating a thick layer $(10-25 \mu \mathrm{m})$ of $\mathrm{Cu}$ over the sample. These cross sections were examined by EPMA so that compositions and x-ray maps of $\mathrm{S}, \mathrm{O}, \mathrm{Na}$, and other coating elements could be obtained.

\section{Results and Discussion Isothermal oxidation behavior}

The isothermal oxidation behavior of RE-doped aluminide diffusion coatings on IN 713LC produced from a cementation pack containing $20 \mathrm{w} / \mathrm{o}$ of $\mathrm{Cr}-10 \mathrm{w} / \mathrm{o} \mathrm{Al}$ masteralloy with various chloride activator salts and/or $\mathrm{RE}$ sources at $1150^{\circ} \mathrm{C}$ for $24 \mathrm{~h}$, using an $\mathrm{AP}$ arrangement, was determined at $1100^{\circ} \mathrm{C}$ in air at a flow rate of $0.1 \mathrm{liter} / \mathrm{min}$ STP. The oxidation kinetics are presented in Fig. 1, and XRD analyses and parabolic rate constants calculated from Fig. 1 are listed and compared to literature values in Table I.

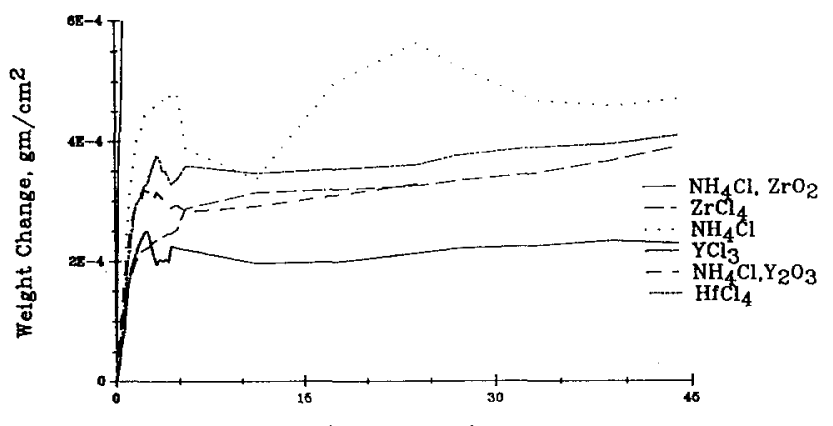

Oxidation Time, hrs.

Fig. 1. Oxidation kinetics for IN $713 \mathrm{LC}$ alloys coated at $1150^{\circ} \mathrm{C}$ for $24 \mathrm{~h}$ in a pack containing various activator salts/RE sources with 20 $\mathrm{w} / \mathrm{o}$ of $\mathrm{Cr}-10 \mathrm{w} / \mathrm{O} \mathrm{Al}$ masteralloy and isothermally oxidized at $1100{ }^{\circ} \mathrm{C}$ in air at a flow rate of 0.1 liter $/ \mathrm{min}$ STP (AP arrangement). 
Table I. Oxidation kinetics and XRD results of IN $713 \mathrm{LC}$ alloy substrates coated at $1150^{\circ} \mathrm{C}$ for $24 \mathrm{~h}$ in a pack containing various activator salts/RE sources with $20 \mathrm{w} / 0$ of $\mathrm{Cr}-10 \mathrm{w} / \mathrm{o} \mathrm{Al}$ masteralloy and isothermally oxidized at $1100^{\circ} \mathrm{C}$ for $44 \mathrm{~h}$ in air at a flow rate of 0.1 liter/min STP, and comparison with literature values (AP arrangement).

\begin{tabular}{lcc}
\hline & $\begin{array}{c}\text { Parabolic } \\
\text { rate constant } \\
\left(\mathrm{g} / \mathrm{cm}^{2} \mathrm{~h}^{1 / 2}\right)\end{array}$ & $\begin{array}{c}\text { XRD phases } \\
\text { and oxides }\end{array}$ \\
\hline $2 \% \mathrm{NH}_{4} \mathrm{Cl}$ & $4.501 \times 10^{-5}$ & $1,2,3$ \\
$2 \% \mathrm{NH}_{4} \mathrm{Cl}, 2 \% \mathrm{ZrO}_{2}$ & $6.201 \times 10^{-4}$ & $1,2,3,4$ \\
$2 \% \mathrm{NH}_{4} \mathrm{Cl}, 2 \% \mathrm{Y}_{2} \mathrm{O}_{3}$ & $2.586 \times 10^{-5}$ & $1,2,6,3$ \\
$4 \% \mathrm{ZrCl}_{4}$ & $4.401 \times 10^{-5}$ & $1,2,4$ \\
$4 \% \mathrm{YCl}_{3}$ & $1.751 \times 10^{-5}$ & $1,2,6$ \\
$4 \% \mathrm{HCl}_{4}$ & $3.942 \times 10^{-5}$ & $1,2,5,3$ \\
\hline
\end{tabular}

Key: $1, \beta-\mathrm{NiAl} ; 2, \mathrm{Al}_{2} \mathrm{O}_{3} ; 3, \mathrm{NiAl}_{2} \mathrm{O}_{4} ; 4, \mathrm{ZrO}_{2} ; 5, \mathrm{HfO}_{2} ;$ and $6, \mathrm{YAlO}_{3}$.

\begin{tabular}{|c|c|c|}
\hline $\begin{array}{l}\text { Alloys } \\
(\mathrm{a} / \mathrm{o})\end{array}$ & $\begin{array}{c}k_{\mathrm{p}} \\
\left(\mathrm{g} / \mathrm{cm}^{2} \mathrm{~h}^{1 / 2}\right)\end{array}$ & Atmosphere \\
\hline $\begin{array}{l}\mathrm{Ni}-42 \mathrm{Al}(5) \\
\mathrm{Ni}-47 \mathrm{Al}-0.05 \mathrm{Zr}(11) \\
\mathrm{Ni}-52 \mathrm{Al}+2 \times 10^{16}\end{array}$ & $\begin{array}{l}4.5 \times 10^{-5} \\
3.8 \times 10^{-5} \\
9.2 \times 10^{-4}\end{array}$ & $\begin{array}{l}0.1 \mathrm{~atm} \mathrm{O}_{2} \\
0.2 \operatorname{atm} \mathrm{O}_{2} \\
1.0 \mathrm{~atm} \mathrm{O}_{2}\end{array}$ \\
\hline
\end{tabular}

True parabolic rate constants, $k_{\mathrm{p}}$, for isothermal oxidation were calculated by linear regression of the weight gain vs. square root of time data, as suggested by Pieraggi. ${ }^{34}$ The data fit produced $R^{2}$ values over 0.90 . A slow-growing $\mathrm{Al}_{2} \mathrm{O}_{3}$ scale was produced on all the $\mathrm{RE}$-doped aluminide coatings. The rate constants for both the undoped and the REdoped, aluminide coatings agreed with those for undoped $\beta-\mathrm{NiAl},{ }^{5}$ for $\mathrm{Y}$-implanted $\beta$-NiAl coatings on $\mathrm{Ni}$-base alloys in pure oxygen ${ }^{16}$ and for bulk $\beta$-NiAl containing other $\mathrm{RE}$ additions at $1100^{\circ} \mathrm{C}^{11}$ (Table I).

The kinetic results were characterized by a short transient oxidation $(\sim 5 \mathrm{~h})$ resulting from the rapid formation of $\mathrm{NiAl}_{2} \mathrm{O}_{4}$ spinel and $(\mathrm{Cr}, \mathrm{Al})_{2} \mathrm{O}_{3}$ scales. Eventually, the spinel was isolated by a steady-state slow-growing $\mathrm{Al}_{2} \mathrm{O}_{3}$ scale. The rate of steady-state oxide growth was comparable for each of the RE-doped aluminide coatings. The $\mathrm{Cr}$ carbide coating produced from a pack containing $2 \mathrm{w} / \mathrm{o} \mathrm{NH}_{4} \mathrm{Cl}$ activator plus $2 \mathrm{w} / \mathrm{o} \mathrm{ZrO}_{2}$ oxidized with a parabolic rate constant that was an order of magnitude higher (Table I).

Representative SEMs of the surface oxides are shown in Fig. 2. A ridged $\mathrm{Al}_{2} \mathrm{O}_{3}$ scale, as typically found on oxidized $\beta-\mathrm{NiAl},{ }^{6}$ was observed on all aluminide coatings. The carbide coatings formed by the $\mathrm{NH}_{4} \mathrm{Cl}$ plus $\mathrm{ZrO}_{2}$ pack produced a compact thick scale comprised of a thin outer $\mathrm{NiAl}_{2} \mathrm{O}_{4}$ spinel layer with an inner $\mathrm{Al}_{2} \mathrm{O}_{3}$ layer containing a large dispersion of $\mathrm{ZrO}_{2}$ particles. For undoped coatings, cracked or spalled scales were evident near grain boundaries of the coating, exposing the voided interface (Fig. 2a and b). Cracking and/or spalling of the oxide was evident also from the oxidation kinetics, because at the end of the transient oxidation stage, a small drop in weight was recorded. For RE-doped coatings, a much smaller fluctuation was measured. As shown in Fig. $2 c$ and d, scale cracking originated near the coating grain boundaries for a Y-doped aluminide coating. However, a tenacious $\mathrm{Al}_{2} \mathrm{O}_{3}$ scale with a trace of $\mathrm{Y}$ was detected by EPMA analysis beneath the outer cracked scale. Other RE-doped aluminide coatings produced uncracked surface oxides. For example, a Hf-doped aluminide coating formed a ridged and relatively flawless external $\mathrm{Al}_{2} \mathrm{O}_{3}$ scale (Fig. 2e). Analysis with XRD identified weak signals for $\mathrm{YAlO}_{3}, \mathrm{ZrO}_{2}$, and $\mathrm{HfO}_{2}$ phases on the $\mathrm{Y}-, \mathrm{Zr}-$, and $\mathrm{Hf}$-doped aluminide coatings, respectively (Table I)

Generally, the RE-doped aluminide coatings produced a continuous slow-growing $\mathrm{Al}_{2} \mathrm{O}_{3}$ scale. However, weight fluctuations from scale spallation made calculations of true parabolic rate constants difficult, so comparison of rate constants for RE-doped and undoped aluminide coatings could not be drawn. Nevertheless, the RE-doped aluminide coatings exhibited overall superior isothermal oxidation behavior for the IN 713LC alloy.

\section{Cyclic Oxidation Behavior}

Powder contacting arrangement.-Cyclic oxidation tests at $1100^{\circ} \mathrm{C}$ in static air of the $\mathrm{Cr} / \mathrm{RE}$-modified aluminide coatings on René 80 alloy substrates, produced by the PC arrangement, were conducted at the NASA Lewis Research Center and some have been presented in a previous publication. ${ }^{35}$ The diffusion coatings were produced from cementation packs containing $25 \mathrm{w} / \mathrm{o}$ of $\mathrm{Cr}-7.5 \mathrm{w} / \mathrm{o} \mathrm{Al}$ masteralloy and 2 w/o of an $\mathrm{NH}_{4} \mathrm{Cl}$ or $\mathrm{RE}$-base activator and/or $\mathrm{RE}$ oxide sources heated at $1150^{\circ} \mathrm{C}$ for $24 \mathrm{~h}$. The original surface compositions for these coatings are tabulated in the preceding paper. $^{2}$ The weight-change measurements $v s$. cycle time are presented in Fig. 3 , and XRD analysis of the surface phases and any spalled oxide collected are listed in Table II from the strongest to the weakest peak. The cyclic oxidation kinetics were compared to the bulk uncoated alloy ${ }^{36}$ and to a commercial low activity aluminide diffusion coating, GE Codep C, for the same alloy substrate.

The $\mathrm{Cr} / \mathrm{RE}$-modified (e.g., $\mathrm{ZrCl}_{4^{-}}$and $\mathrm{YCl}_{3}$-activated packs) and the Cr-modified (e.g., $\mathrm{NH}_{4} \mathrm{Cl}$-activated) aluminide coatings improved the adherence and lifetimes of $\mathrm{Al}_{2} \mathrm{O}_{3}$ scales on the coated substrates considerably. Overall, the cyclic oxidation behavior was dependent on the structure of the coating itself (aluminide or carbide) and the presence of the RE in the coating. For example, a $2 \mathrm{w} / \mathrm{o}$ $\mathrm{AlCl}_{3}$-activated pack containing $2 \mathrm{w} / \mathrm{o} \mathrm{ZrO}_{2}$ produced a $\mathrm{Cr}_{23} \mathrm{C}_{6}$ carbide coating which failed to protect the substrate (Fig. 3a). The remaining pack chemistries produced aluminide coatings which provided exceptional protection. However coatings produced from packs containing $\mathrm{ZrO}_{2}$ additions failed to improve coating lifetimes or scale adherence, which can be attributed to the excessive amounts of $\mathrm{Zr}$ in the aluminide coatings mainly as $\mathrm{ZrO}_{2}$ entrapment. ${ }^{2}$ For Fig. 3 and Table II, outward-grown aluminide coatings also possessed various amounts of entrapped

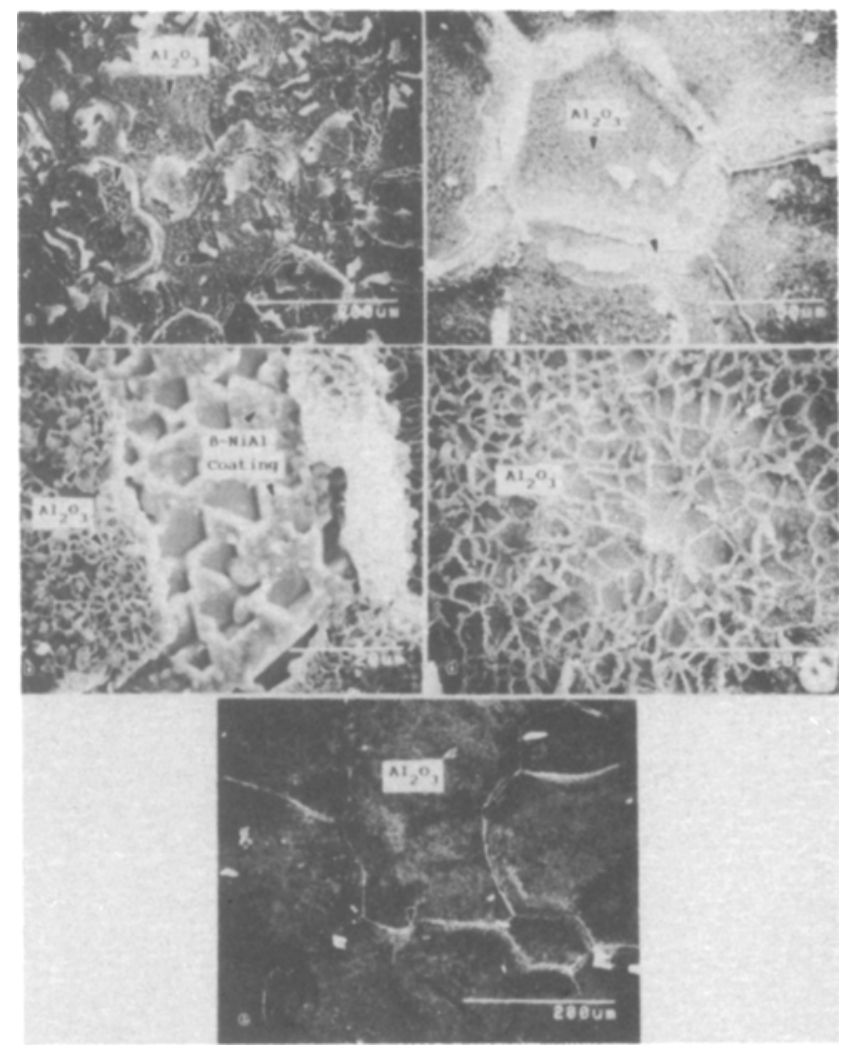

Fig. 2. Surface scanning electron micrograph of an IN 713LC alloy coated at $1150^{\circ} \mathrm{C}$ for $24 \mathrm{~h}$ in a pack containing (a, $b$, top) $2 \mathrm{w} / \mathrm{o}$ $\mathrm{NH}_{4} \mathrm{Cl},\left(\mathrm{c}, \mathrm{d}\right.$, middle) $2 \mathrm{w} / \mathrm{o} \mathrm{NH}_{4} \mathrm{Cl}$ plus $2 \mathrm{w} / \mathrm{o} \mathrm{Y}_{2} \mathrm{O}_{3}$, and (e, bottom) $\mathrm{w} / 0 \mathrm{HFCl}_{4}$ with $20 \mathrm{w} / \mathrm{o}$ of $\mathrm{Cr}-10 \mathrm{w} / \mathrm{o} \mathrm{Al}$ masteralloy and isothermally oxidized at $1100^{\circ} \mathrm{C}$ for $44 \mathrm{~h}$ in air at a flow rate of $0.1 \mathrm{liter} / \mathrm{min}$ STP (AP arrangement). 

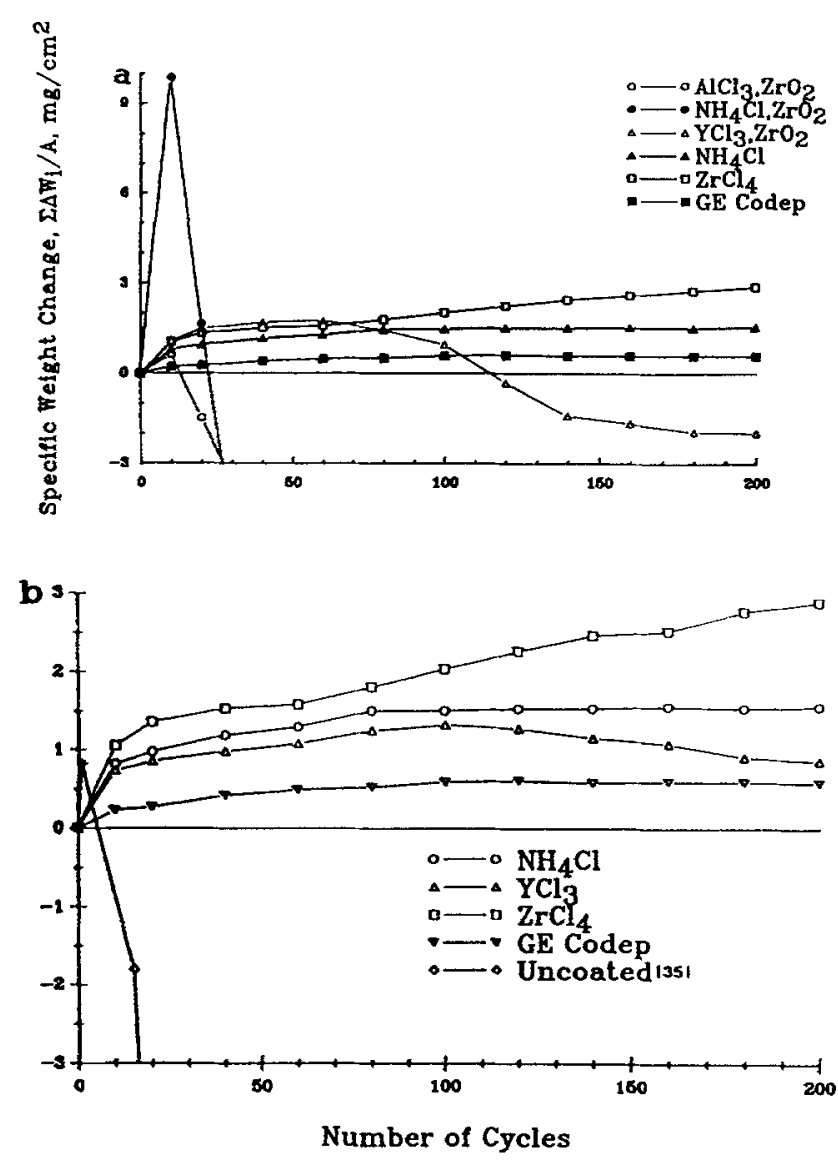

Fig. 3. Oxidation kinetics for a René 80 alloy coated at $1150^{\circ} \mathrm{C}$ for $24 \mathrm{~h}$ with a suitable $\mathrm{Cr}$-Al binary masteralloy and cyclically oxidized at $1100^{\circ} \mathrm{C}$ in static air for up to $2001 \mathrm{~h}$ cycles: (a) $\mathrm{ZrO}_{2}$ source, and (b) RE-base activators (PC arrangement).

$\mathrm{Al}_{2} \mathrm{O}_{3}$ filler powder, depending on the physical state of the activator used. Liquid activator salts, such as $\mathrm{YCl}_{3}$, cause wetting of the pack powders and aggregation of the particles. Volatile activator salts, such as $\mathrm{ZrCl}_{4}$, do not wet pack powders, so a more random dispersion and larger amount of entrapment are produced.

Entrapped oxide particles can degrade the aluminide coating severely and cause the premature failure of the protective $\mathrm{Al}_{2} \mathrm{O}_{3}$ seales, even on coatings containing sufficient RE content (Fig. 3). Entrapped particles also can initiate fatigue cracks at the surface, thereby reducing the overall mechanical durability (e.g., thermal fatigue resistance) of the coated component.

Analysis with XRD of oxidized coatings indicated that successful coatings produced an $\alpha-\mathrm{Al}_{2} \mathrm{O}_{3}$ scale with minor peaks of $\mathrm{NiAl}_{2} \mathrm{O}_{4}$ and $\mathrm{TiO}_{2}$ phases, with no spall collected after 200 cycles. Unprotective coatings $(e . g$., carbide or $\mathrm{ZrO}_{2}$ entrapped coatings) failed to form an adherent $\mathrm{Al}_{2} \mathrm{O}_{3}$ scale; instead external $\mathrm{Cr}_{2} \mathrm{O}_{3}, \mathrm{NiO}, \mathrm{TiO}_{2}$, and spinel phases formed and spalled during thermal cycling.

\section{Table II. XRD results of René 80 alloy substrates coated at $1150^{\circ} \mathrm{C}$ for $24 \mathrm{~h}$ in a pack containing various activator salts/RE sources with $25 \mathrm{w} / \mathrm{\circ}$ of $\mathrm{Cr}-7.5 \mathrm{w} / 0 \mathrm{Al}$ masteralloy and cyclically oxidized at $1100^{\circ} \mathrm{C}$ in static air for $200 \mathrm{ith}$ cycles. (PC arrangement).}

\begin{tabular}{lcc}
\hline Pack chemistry & Oxide phase(s) & Spall \\
\hline $\mathrm{NH}_{4} \mathrm{Cl}, \mathrm{ZrO}_{2}$ & $\mathrm{NiAl}_{2} \mathrm{O}_{4}, \mathrm{TiO}_{2}, \mathrm{ZrO}_{2}, \mathrm{Al}_{2} \mathrm{O}_{3}$ & $\mathrm{NiAl}_{2} \mathrm{O}_{4}, \mathrm{NiO}$ \\
$\mathrm{YCl}_{3}, \mathrm{ZrO}_{2}$ & $\mathrm{Al}_{2} \mathrm{O}_{3}, \mathrm{NiAl}_{2} \mathrm{O}_{4}, \mathrm{TiO}_{2}$ & $\mathrm{NiAl}_{2} \mathrm{O}_{4}, \mathrm{TiO}_{2}, \mathrm{Al}_{2} \mathrm{O}_{3}$ \\
$\mathrm{NH}_{4} \mathrm{Cl}$ & $\mathrm{Al}_{2} \mathrm{O}_{3}, \mathrm{TiO}_{2}, \mathrm{NiAl}_{2} \mathrm{O}_{4}$ & none \\
$\mathrm{YCl}_{3}$ & $\mathrm{Al}_{2} \mathrm{O}_{3}, \mathrm{NiAl}_{2} \mathrm{O}_{4}$ & none \\
$\mathrm{ZrCl}_{4}$ & $\mathrm{Al}_{2} \mathrm{O}_{3}, \mathrm{NiAl}_{2} \mathrm{O}_{4}$ & none \\
$\mathrm{GE} \mathrm{Codep} \mathrm{C}$ & $\mathrm{Al}_{2} \mathrm{O}_{3}, \mathrm{NiAl}_{2} \mathrm{O}_{4}$ & none
\end{tabular}

$\mathrm{XRD}$ results are all listed from strongest to weakest peaks.

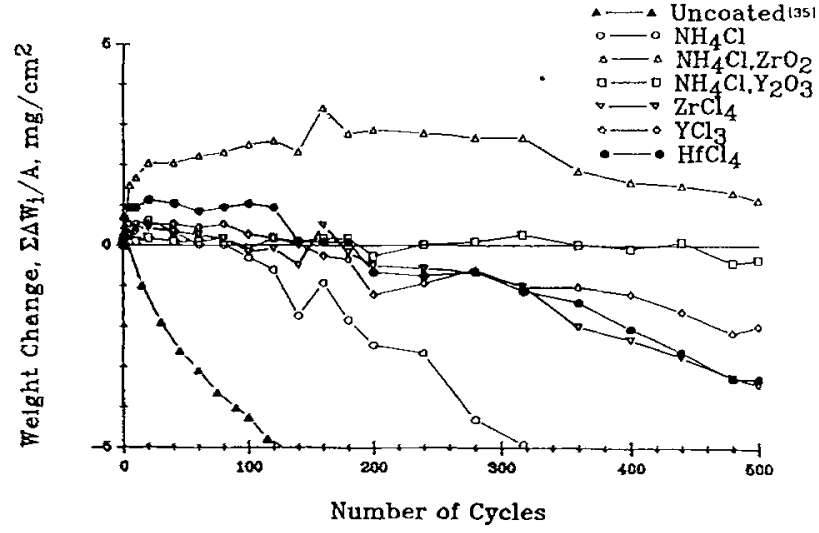

Fig. 4. Oxidation kinetics for an IN $713 \mathrm{LC}$ alloy coated at $1150^{\circ} \mathrm{C}$ for $24 \mathrm{~h}$ in a pack containing $20 \mathrm{w} / 0$ of $\mathrm{Cr}-10 \mathrm{w} / 0$ Al masteralloy with various activator salts/RE sources and cyclically oxidized at $1100^{\circ} \mathrm{C}$ in static air for up to $5001 \mathrm{~h}$ cycles (AP arrangement).

For successful coatings after oxidation at $1100^{\circ} \mathrm{C}$ for 200 $1 \mathrm{~h}$ cycles, a thin and adherent $\mathrm{Al}_{2} \mathrm{O}_{3}$ scale was present on the surface, beneath which $\mathrm{Al}_{2} \mathrm{O}_{3}$ entrapment was evident. After oxidation, the coating consisted of a single-phase $\beta$ NiAl compound without any $\alpha-\mathrm{Cr}$ second-phase particles Due to interdiffusion between the Ni-base substrate and the coating, a second chain of W-, Cr-, and Mo-rich carbides began to form beneath the original one. For nonprotective coatings, the consumption of $\mathrm{Al}$ led to a nonprotective and nonadherent $\mathrm{Al}_{2} \mathrm{O}_{3}$ scale. No external $\beta-\mathrm{NiAl}$ coating was present; instead, a two-phase $\left(\gamma+\gamma^{\prime}\right)$ surface layer with little or no interdiffusion zone was observed, typical of an uncoated substrate. Although several coatings formed protective $\mathrm{Al}_{2} \mathrm{O}_{3}$ scales, an improvement over GE Codep $\mathrm{C}$ was not realized. In general, the PC arrangement is not acceptable.

Above pack arrangement.-Cyclic oxidation tests were done at $1100^{\circ} \mathrm{C}$ in static air for entrapment-free $\mathrm{Cr} / \mathrm{RE}$ modified and RE-doped aluminide coatings on René 80 and IN 713LC and on IN 713LC alloy substrates. The weightchange measurements vs. cycle time are presented in Fig. 4-6, and XRD analyses of the surface phases are listed in Tables III and IV. The oxidation behavior of both $\mathrm{Cr} / \mathrm{RE}-$ modified and RE-doped aluminide diffusion coatings is summarized in Table $\mathrm{V}$.

RE-doped aluminide coatings.-Figures 7 and 8 illustrate representative cross-sectional and surface microstructures, respectively, of RE-doped aluminide coatings cyclically oxidized for 500 cycles. The cyclic oxidation behavior followed three general types of attack: (i) a planar Al depletion front (e.g., Fig. 7c), (ii) a planar Al depletion front with associated internal oxidation (e.g., Fig. 7b), or (iii) localized $\mathrm{Al}$ depletion fronts along the surface and/or grain boundaries (e.g., Fig. 7a). In Fig. 7a, localized Al depletion led to the formation of the lower aluminide phase, $\gamma^{\prime}-\mathrm{Ni}_{3} \mathrm{Al}$, and localized spalling to bare metal as indicated in Fig. 8a and b. The localized spalling may explain the weight fluctuations in the kinetic results of Fig. 4. According to SIMS analysis, ${ }^{2} \mathrm{Y}$ deposition was sufficient but localized in the surface of the aluminide coating layer. Generally, the Y-doped aluminide coatings improved the adherence of $\alpha-\mathrm{Al}_{2} \mathrm{O}_{3}$ scales (Fig. 4). In Fig. $7 \mathrm{a}$, an additional interdiffusion zone containing ( $\mathrm{Nb}, \mathrm{Mo}, \mathrm{Cr}$, Ti)-rich carbides is observed beneath the original zone. However, this further interdiffusion between the substrate and the coating during oxidation did not affect the overall cyclic oxidation behavior.

Coatings produced from $\mathrm{RE}$-base chloride activator salts (Fig. 7b, c, and d) were characterized by a $15-25-\mu \mathrm{m}$ thick Al depletion zone (i.e., $\gamma^{\prime}-\mathrm{Ni}_{3} \mathrm{Al}$ layer), deterioration of the interdiffusion zone, and the formation of nonprotective $\mathrm{NiAl}_{2} \mathrm{O}_{4}$ and $\mathrm{TiO}_{2}$ scales (Table III). Undoped (RE-free) aluminide coatings were characterized by excessive depletion 
of $\mathrm{Al}(>40 \mu \mathrm{m})$, transformation into the lower aluminide phase (i.e., $\gamma^{\prime}-\mathrm{Ni}_{3} \mathrm{Al}$ ) and even the $\mathrm{Ni}$ solid solution (i.e., $\gamma-\mathrm{Ni}$ ), and interdiffusion with the substrate (e.g., Fig. 4 and $7 d)$.

Figure $7 \mathrm{~b}$ illustrates another type of attack. Because of excessive levels of zirconium $(0.2-0.3 \mathrm{a} / \mathrm{o})$ in the aluminide coating, internal oxides rich in $\mathrm{Al}$ and $\mathrm{Zr}$ were detected by EPMA analysis within the $\mathrm{Al}$ depletion zone $\left(\gamma^{\prime}-\mathrm{Ni}_{3} \mathrm{Al}\right.$ layer) of the coating. Zirconia $\left(\mathrm{ZrO}_{2}\right)$ particles also were evident within the $\mathrm{Al}_{2} \mathrm{O}_{3}$ scale of the oxidized surface (indicated by arrows in Fig. 8e) and were detected by the XRD analysis (Table III). Although an Al depletion zone was apparent for all the coatings produced with $\mathrm{RE}$-base chloride activators, the coating produced from a pack containing $2 \mathrm{w} / \mathrm{O} \mathrm{NH} \mathrm{NCl}_{4} \mathrm{Cctivator}$ plus $2 \mathrm{w} / \mathrm{o} \mathrm{ZrO}_{2}$ (Fig. $7 \mathrm{~b}$ ) formed $\mathrm{Zr}$ and Al-rich oxide pegs which seemed to anchor and improve the adherence of the $\mathrm{Al}_{2} \mathrm{O}_{3}$ scale (Fig. 4). This behavior is typical for $\mathrm{Zr}$-doped, $\mathrm{Ni}_{3} \mathrm{Al}$ compounds. ${ }^{37}$ Although the $\mathrm{RE}$ content deposited from RE-base chloride activators was not excessive, no internal oxide pegs were observed after 500 cycles. Those coatings offered limited improvem ment (up to 300 cycles) in scale adherence compared to the coatings produced with a RE-oxide source (Fig. 4). Scanning electron micrographs of the oxidized surfaces revealed rough and textured areas where nonprotective $\mathrm{NiAl}_{2} \mathrm{O}_{4}$ and $\mathrm{Al}_{2} \mathrm{O}_{3}$ scales had spalled, exposing the $\mathrm{Al}$ depleted $\mathrm{Ni}_{3} \mathrm{Al}$ surface layer (Fig. $8 \mathrm{c}$ and $\mathrm{d}$ ).

Overall, RE-doped aluminide coatings offered considerable improvement in the adherence of $\mathrm{Al}_{2} \mathrm{O}_{3}$ scales compared to RE-free aluminide coatings and uncoated substrates (Fig. 4). The cyclic oxidation behavior of the RE-doped aluminide coatings was dependent on the physical state of the RE source. For example, the RE oxide sources were present in the pack throughout the coating process and deposited more effective $\mathrm{RE}$ levels (e.g. $\mathrm{NH}_{4} \mathrm{Cl}$-activated packs with $\mathrm{ZrO}_{2}$ or $\mathrm{Y}_{2} \mathrm{O}_{3}$ sources), whereas $\mathrm{RE}$-base chloride activators were extremely volatile $\mathrm{e}^{2}$ and failed to deposit sufficient RE levels to improve scale adherence for the entire 500 cycles.
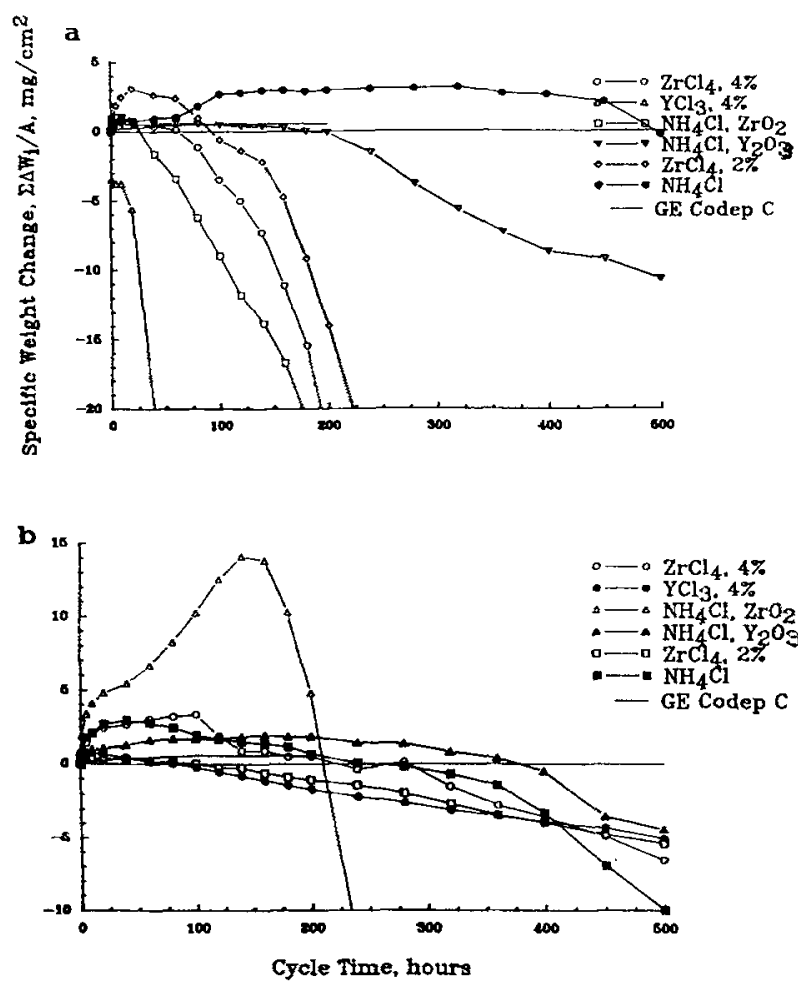

Fig. 5. Oxidation kinetics for (a) René 80, and (b) IN $713 L \mathrm{C}$ alloys coated at $1150^{\circ} \mathrm{C}$ for $4 \mathrm{~h}$ in a pack containing various activator salts/RE sources with $15 \mathrm{w} / \mathrm{o}$ of $\mathrm{Cr}-7.5 \mathrm{w} / \mathrm{o}$ Al masteralloy and cyclically oxidized at $1100^{\circ} \mathrm{C}$ in static air for up to $5001 \mathrm{~h}$ cycles (AP arrangement).
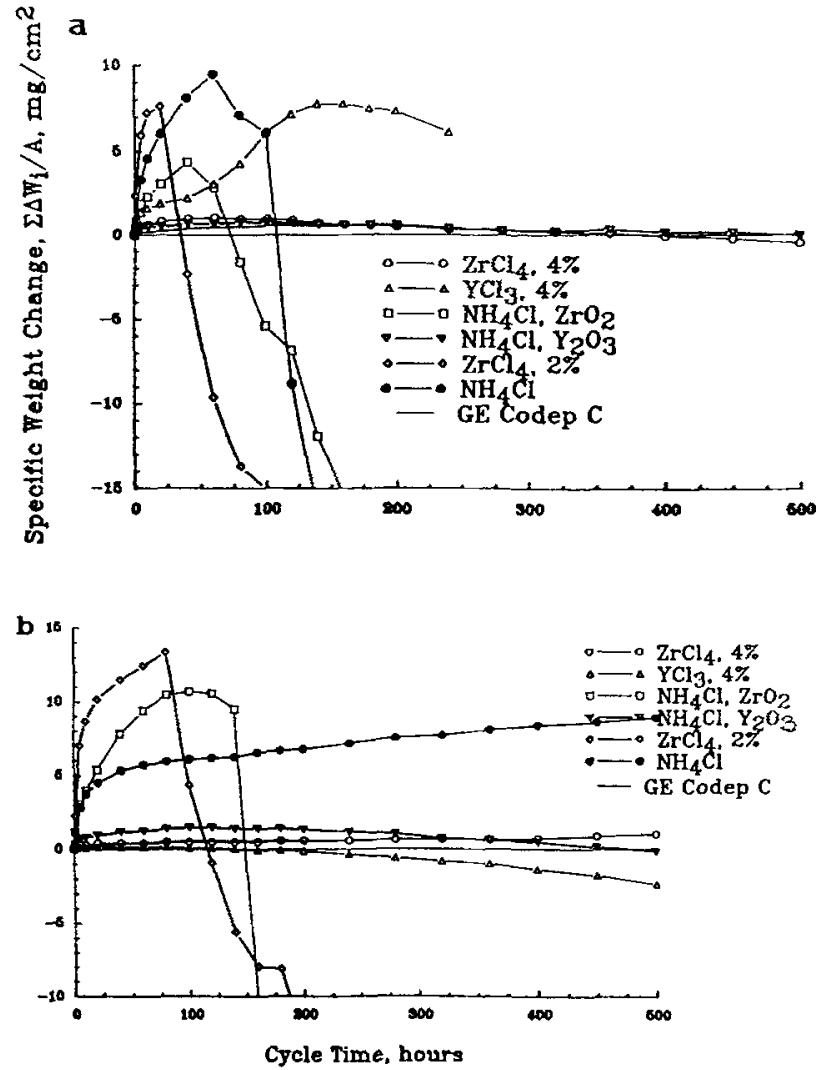

Fig. 6. Oxidation kinetics for (a) René 80, and (b) IN 713LC alloys coated at $1150^{\circ} \mathrm{C}$ for $24 \mathrm{~h}$ in a pack containing various activator salts/RE sources with $15 \mathrm{w} / \mathrm{o}$ of $\mathrm{Cr}-7.5 \mathrm{w} / \mathrm{O} \mathrm{Al}$ masteralloy and cyclically oxidized at $1100^{\circ} \mathrm{C}$ in static air for up to $5001 \mathrm{~h}$ cycles (AP arrangement).

$C r / R E$-modified aluminide coatings.-The cyclic oxidation behavior of the $\mathrm{Cr} / \mathrm{RE}$-modified aluminide coatings was slightly different from the RE-doped aluminide coatings. First, the $\mathrm{Cr}(5.5-8.0 \mathrm{a} / \mathrm{o})$ plus $\mathrm{RE}(0.02-0.30 \mathrm{a} / \mathrm{o})$ additions led to improved scale adherence for coatings produced from only certain pack chemistries, compared to the RE-doped aluminide coatings (Fig. 5 and 6). Second, the interdiffusion zones coarsened and broadened more noticeably during the oxidation exposures. However, the degraded interdiffusion zones did not limit the effectiveness of the RE-modified aluminide coatings.

The weight-change measurements of Fig. 5 and 6 and the XRD analyses in Table IV have identified several pack chemistries which improved the adherence of $\mathrm{Al}_{2} \mathrm{O}_{3}$ scales independent of the coating thickness. Overall, the best coatings were produced from packs containing either $4 \mathrm{w} / \mathrm{O}$ $\mathrm{ZrCl}_{4}, 4$ w/o YCl 3 , or $2 \mathrm{w} / \mathrm{o} \mathrm{NH}_{4} \mathrm{Cl}$ plus $2 \mathrm{w} / \mathrm{o} \mathrm{Y}_{2} \mathrm{O}_{3}$, but the first two chloride activators did not produce optimum cyclic oxidation behavior for the RE-doped aluminide coatings. Although both $\mathrm{Cr} / \mathrm{RE}$-modified and RE-doped aluminide coatings generated $\mathrm{Al}$ depletion zones, the $\mathrm{Cr} /$

Table III. XRD results of IN 713LC alloy substrates coated at $1150^{\circ} \mathrm{C}$ for $24 \mathrm{~h}$ in a pack containing various activator salts/RE sources with $20 \mathrm{w} / 0 \mathrm{Cr}-10 \mathrm{w} / \mathrm{o}$ Al masteralloy and cyclically oxidized at $1100^{\circ} \mathrm{C}$ in static air for $5001 \mathrm{~h}$ cycles (AP arrangement).

Pack chemistry Oxides phase(s)

$\begin{array}{lc}\mathrm{NH}_{4} \mathrm{Cl} & 1,5,2,4 \\ \mathrm{NH}_{4} \mathrm{Cl}, \mathrm{Y}_{2} \mathrm{O}_{3} & 1,2,5,4 \\ \mathrm{NH}_{4} \mathrm{Cl}, \mathrm{ZrO}_{2} & 1,5,2,6 \\ \mathrm{YCl}_{3} & 5,1,2,4 \\ \mathrm{ZrCl}_{4} & 5,1,2,4,6 \\ \mathrm{HfCl}_{4} & 5,1,2,4\end{array}$

Key: $1, \mathrm{Al}_{2} \mathrm{O}_{3} ; 2, \mathrm{NiAl}_{2} \mathrm{O}_{4} ; 3, \mathrm{NiO}_{4} 4, \mathrm{TiO}_{2} ; 5, \mathrm{Ni}_{3} \mathrm{Al}$; and $6, \mathrm{ZrO}_{2}$ 


\begin{tabular}{|c|c|c|c|c|}
\hline \multirow[b]{2}{*}{ Pack chemistry } & \multicolumn{2}{|c|}{ René 80} & \multicolumn{2}{|c|}{ IN 713LC } \\
\hline & $4 \mathrm{~h}$ & $24 \mathrm{~h}$ & $4 \mathrm{~h}$ & $24 \mathrm{~h}$ \\
\hline $\begin{array}{l}2 \% \mathrm{ZrCl}_{4} \\
4 \% \mathrm{ZrCl}_{4} \\
4 \% \mathrm{YCl}_{3} \\
2 \% \mathrm{NH}_{4} \mathrm{Cl} \\
2 \% \mathrm{NH}_{4} \mathrm{Cl}, 2 \% \mathrm{Y}_{2} \mathrm{O}_{3} \\
2 \% \mathrm{NH}_{4} \mathrm{Cl}, 2 \% \mathrm{ZrO}_{2}\end{array}$ & $\begin{array}{c}\mathrm{n} / \mathrm{a} \\
3,2,4,1 \\
\mathrm{n} / \mathrm{a} \\
1,4,3 \\
1,2,4 \\
1,3,4\end{array}$ & $\begin{array}{c}1,2,3 \\
1,2,3 \\
1,2,4 \\
1,4,2,3,6 \\
1,2,3 \\
1,4,3,2,6\end{array}$ & $\begin{array}{l}1,3 \\
1,2,3 \\
1,2,3 \\
1,2,3 \\
1,2,3 \\
1,4,3\end{array}$ & $\begin{array}{c}1,2,3 \\
2,3,5 \\
1,2,3 \\
1,2,3 \\
1,2,5 \\
1,4,3,2\end{array}$ \\
\hline
\end{tabular}

Key: $1, \mathrm{Ni}_{3} \mathrm{Al}, 2, \mathrm{Al}_{2} \mathrm{O}_{3}, 3, \mathrm{NiAl}_{2} \mathrm{O}_{4} ; 4, \mathrm{Ni} ; 5, \mathrm{\beta}-\mathrm{NiAl} ; 6, \mathrm{TiO}_{2} ;$ and $\mathrm{n} / \mathrm{a}$, not analyzed.

RE-modified coatings were more protective. Possibly, the hypostoichiometric ( 40 a/o Al compared to 45 a/o Al) $\beta$ $\mathrm{NiAl}$ phase in the $\mathrm{Cr} / \mathrm{RE}$-modified aluminide coatings contained higher solubilities for $\mathrm{Zr}$ and $\mathrm{Y}$, which provided improvement in the scale adherence. Alternatively, as for the $\mathrm{NiCrAl}$ alloy system, ${ }^{38}$ the $\mathrm{Cr}$ additions $(\sim 5.5$ to $8.0 \mathrm{a} / \mathrm{o} \mathrm{Cr})$ to the $\beta$-NiAl phase may have enhanced the $\mathrm{Al}$ diffusivity, allowing for more rapid formation of the protective $\mathrm{Al}_{2} \mathrm{O}_{3}$ scale. This explains the thicker $\mathrm{Al}$ depletion zones $\left(\mathrm{Ni}_{3} \mathrm{Al}\right.$ layers) in the $\mathrm{Cr} / \mathrm{RE}$-modified coatings compared to the RE-doped coatings (compares Fig. $7 \mathrm{a}$ and 9,10 , or 11) and, possibly, the relatively adherent $\mathrm{Al}_{2} \mathrm{O}_{3}$ scales grown on the $\mathrm{Ni}_{3} \mathrm{Al}$ surface layers. In addition, the $\mathrm{Cr}$ enrichment may have increased the Al diffusivity in the $\gamma^{\prime}-\mathrm{Ni}_{3} \mathrm{Al}(\sim 4$ to 5 a/o $\mathrm{Cr})$ and the $\gamma-\mathrm{Ni}(\sim 15$ to $20 \mathrm{a} / \mathrm{o} \mathrm{Cr})$ phases, to enable the growth of a more protective $\mathrm{Al}_{2} \mathrm{O}_{3}$ scale (Fig. 10 and 11).

The $\beta-\mathrm{NiAl}$ phase is an ordered intermetallic compound with the $\mathrm{B} 2(\mathrm{CsCl})$ crystal structure. The $\mathrm{NiAl}$ phase exists over a wide range of stoichiometry, from 30 to $58 \mathrm{a} / \mathrm{o} \mathrm{Al}$, and exhibits intrinsic disorder by antistructure defects, i.e., by mutual substitution. For hypostoichiometric (Ni-rich) compounds, $\mathrm{Al}$ atoms are replaced by $\mathrm{Ni}$ atoms; whereas, for the hyperstoichiometric (Al-rich) compound, $\mathrm{Ni}$ atoms are replaced by $\mathrm{Al}$ atoms from 50 to 50.5 a/o $\mathrm{Al}$, but $\mathrm{Ni}$ vacancies compensate for further increases in $\mathrm{Al}$ composition. ${ }^{39,40}$ In $\mathrm{Cr} / \mathrm{RE}$-modified aluminide coatings, $\mathrm{Cr}$ atoms substitute for $\mathrm{Al}$ atoms in the hypostoichiometric lattice. Since the $\mathrm{CrAl}$ compound possesses a larger disorder and vacancy concentration, $\mathrm{Cr}$ additions into the $\mathrm{NiAl}$ compound may inject vacancies into this lattice. ${ }^{40}$ These excess vacancies could increase the $\mathrm{Al}, \mathrm{Cr}$, and $\mathrm{Ni}$ diffusivities, thereby increasing the rate of $\mathrm{Al}$ depletion and promoting interdiffusion degradation, i.e., a coarsened microstructure. The interdiffusion degradation of high activity aluminide diffusion coatings on single-crystal $\mathrm{Ni}$-base superalloys was reported recently. ${ }^{41}$ The transformation from a B2-type $\mathrm{NiAl}$ phase to a $\mathrm{L}_{2}-\mathrm{Ni}_{3}$ (Al, Ti) phase during exposure at temperatures of 850 and $950^{\circ} \mathrm{C}$ in vacuum, nucleated at grain and interphase boundaries within the interdiffusion zone. These boundaries can possess excess vacancies, thereby promoting rapid $\mathrm{Al}$ boundary diffusion and interdiffusion degradation.

$\dot{\mathrm{RE}}$-free and RE-lean coatings, or ones produced from a pack containing $2 \mathrm{w} / \mathrm{o} \mathrm{NH}_{4} \mathrm{Cl}$ plus $2 \mathrm{w} / \mathrm{o} \mathrm{ZrO}_{2}$ showed consistently poor cyclic oxidation behavior. Coatings produced from this pack failed to produce an aluminide coating layer; instead, an external chromium carbide layer $\left(\mathrm{Cr}_{23} \mathrm{C}_{6}\right)$ was formed with poor cyclic oxidation resistance. Similarly, carbide coatings were produced from two other packs: $2 \mathrm{w} / \mathrm{o} \mathrm{ZrCl}_{4}$ and $\mathrm{NH}_{4} \mathrm{Cl}$ for René 80 substrates. To produce an aluminide coating, a masteralloy containing a higher $\mathrm{Al}$ activity (i.e., $\mathrm{Cr}-10 \mathrm{w} / \mathrm{O} \mathrm{Al}$ ) would be required, but then, the aluminide coating only had about $2 \mathrm{a} / \mathrm{o} \mathrm{Cr}$.

Table V. Cyclic oxidation results conducted at $1100^{\circ} \mathrm{C}$ in static air.

\begin{tabular}{|c|c|c|c|c|}
\hline Alloy & $\begin{array}{c}\text { Activator/RE source } \\
(\mathrm{w} / \mathrm{o})\end{array}$ & $\begin{array}{l}\text { Masteralloy } \\
(w / o)\end{array}$ & Mode of failure or other comments & $\begin{array}{l}\text { Wt. change } \\
\left./ \mathrm{cm}^{2}\right) / \text { cycles }(\mathrm{h})\end{array}$ \\
\hline 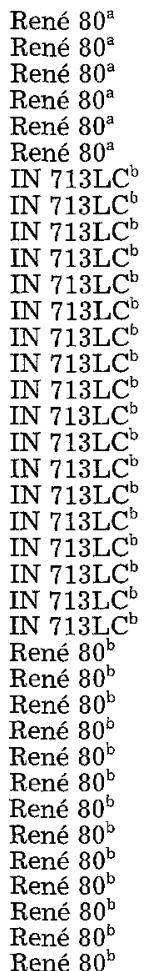 & $\begin{array}{c}\mathrm{AlCl}_{3} /(2) \mathrm{ZrO}_{2} \\
\mathrm{NH}_{4} \mathrm{Cl} /(2) \mathrm{ZrO}_{2} \\
\mathrm{YCl}_{3} /(2) \mathrm{ZrO}_{2} \\
\mathrm{NH}_{4} \mathrm{Cl} \\
\mathrm{ZrCl}_{4} \\
\mathrm{YCl}_{3} \\
\mathrm{NH}_{4} \mathrm{Cl} \\
(4) \mathrm{ZrCl}_{4} \\
(4) \mathrm{HfCl}_{4} \\
(4) \mathrm{YCl}_{3} \\
\mathrm{NH}_{4} \mathrm{Cl} /(2) \mathrm{ZrO}_{2} \\
\mathrm{NH}_{4} \mathrm{Cl} /(2) \mathrm{Y}_{2} \mathrm{O}_{3} \\
\mathrm{NH}_{4} \mathrm{Cl}_{3} \\
\mathrm{NH}_{4} \mathrm{Cl} /(2) \mathrm{Y}_{2} \mathrm{O}_{3} \\
(4) \mathrm{YCl}_{3} \\
\mathrm{ZrCl}_{4} \\
(4) \mathrm{ZrCl}_{4} \\
\mathrm{NH}_{4} \mathrm{Cl} /(2) \mathrm{ZrO}_{2} \\
\mathrm{NH}_{4} \mathrm{Cl} \\
\mathrm{NH}_{4} \mathrm{Cl} /(2) \mathrm{Y}_{2} \mathrm{O}_{3} \\
(4) \mathrm{YCl}_{3} \\
\mathrm{ZrCl}_{4} \\
(4) \mathrm{ZrCl}_{4} \\
\mathrm{NH}_{4} \mathrm{Cl} /(2) \mathrm{ZrO}_{2} \\
\mathrm{NH} \mathrm{Cl}_{2} \\
\mathrm{NH}_{4} \mathrm{Cl} /(2) \mathrm{Y}_{2} \mathrm{O}_{3} \\
(4) \mathrm{YCl}_{3} \\
\mathrm{ZrCl}_{4} \\
(4) \mathrm{ZrCl}_{4} \\
\mathrm{NH}_{4} \mathrm{Cl} /(2) \mathrm{ZrO}_{2} \\
\mathrm{NH}_{4} \mathrm{Cl}_{2} \\
\mathrm{NH}_{4} \mathrm{Cl} /(2) \mathrm{Y}_{2} \mathrm{O}_{3} \\
(4) \mathrm{YCl}_{3} \\
\mathrm{ZrCl}_{4} \\
(4) \mathrm{ZrCl}_{4} \\
\mathrm{NH}_{4} \mathrm{Cl} /(2) \mathrm{ZrO}_{2} \\
\mathrm{NH} \mathrm{Cl}\end{array}$ & 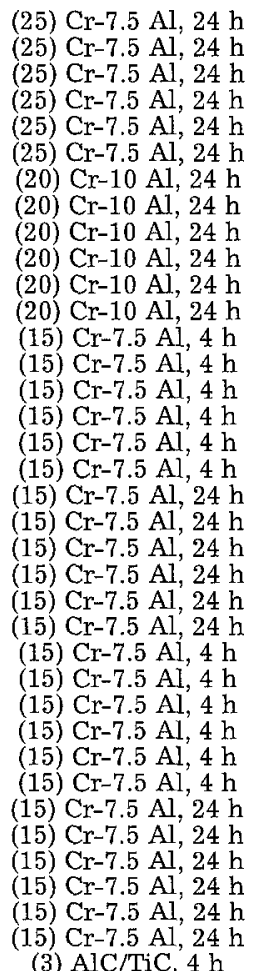 & 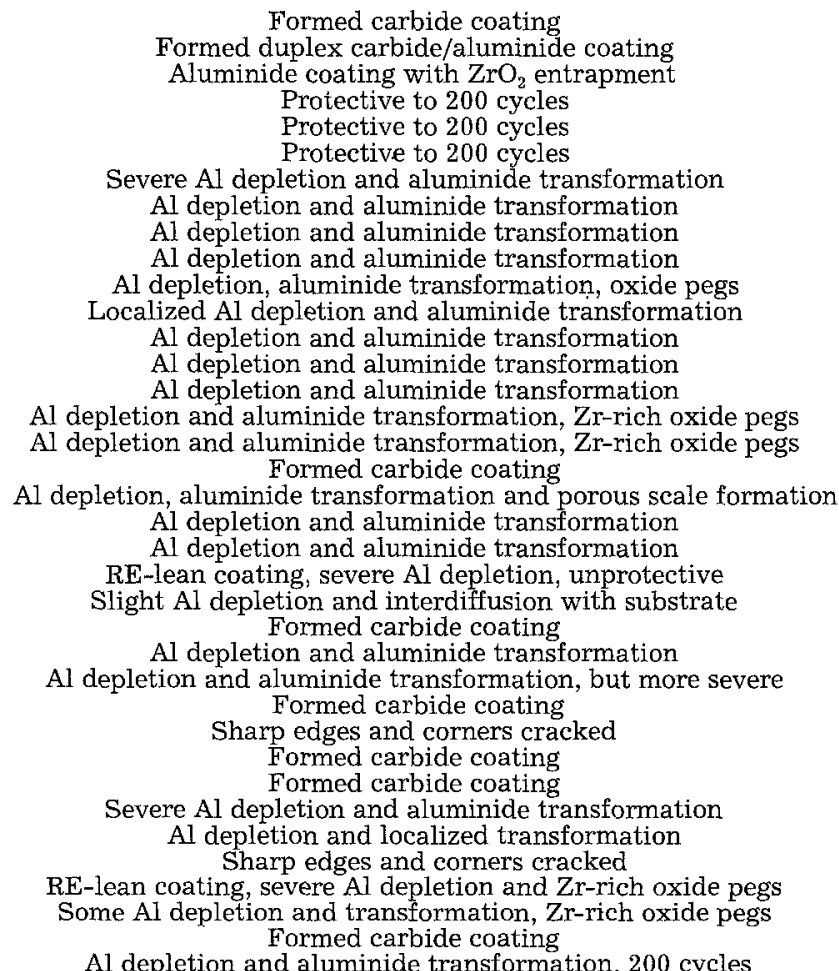 & $\begin{array}{r}-22.6 / 100 \\
-46.1 / 100 \\
-2.0 / 200 \\
1.55 / 200 \\
2.87 / 200 \\
0.85 / 200 \\
-10.3 / 500 \\
-3.42 / 500 \\
-3.27 / 500 \\
-1.98 / 500 \\
1.11 / 500 \\
-0.35 / 500 \\
-9.97 / 500 \\
-4.44 / 500 \\
-5.07 / 500 \\
-5.43 / 500 \\
-6.59 / 500 \\
-12.8 / 200 \\
8.94 / 500 \\
-0.15 / 500 \\
-2.40 / 500 \\
-33.3 / 500 \\
-0.48 / 500 \\
-50.8 / 320 \\
-0.26 / 500 \\
-10.7 / 500 \\
-370 / 280 \\
-96.1 / 450 \\
-60.2 / 280 \\
-79.1 / 280 \\
-52.9 / 320 \\
0.00 / 500 \\
6.09 / 240 \\
-76.6 / 320 \\
-0.48 / 500 \\
-48.3 / 320\end{array}$ \\
\hline
\end{tabular}

$2 \mathrm{w} / \mathrm{o}$ of activators was used unless otherwise noted.

$\mathrm{PC}$ arrangement.

${ }^{\mathrm{b}} \mathrm{AP}$ arrangement. 


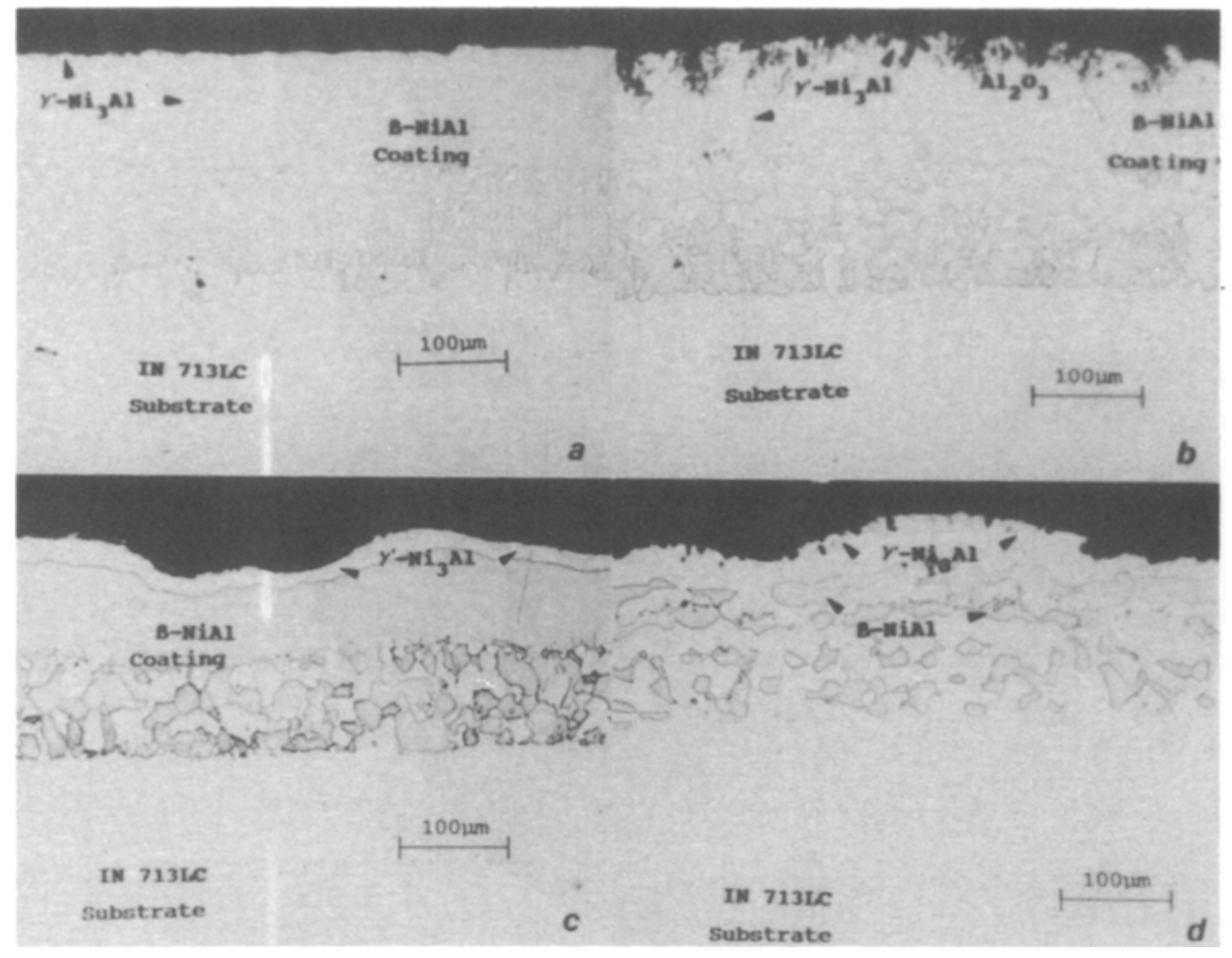

Fig. 7. Cross-sectional optical micrograph of an $\mathrm{N} 713 \mathrm{LC}$ alloy coated of $1150^{\circ} \mathrm{C}$ for $24 \mathrm{~h}$ in a pack containing (a) $2 \mathrm{w} / 0 \mathrm{NH}_{4} \mathrm{Cl}$ plus $2 \mathrm{w} / 0 \mathrm{Y}_{2} \mathrm{O}_{3}$, (b) $2 \mathrm{w} / \mathrm{o} \mathrm{NH} \mathrm{NH}_{4} \mathrm{Cl}$ plus $2 \mathrm{w} / 0 \mathrm{ZrO}_{2}$, (c) $4 \mathrm{w} / \mathrm{o} \mathrm{HFCl}$, and (d) $2 \mathrm{w} / \mathrm{o} \mathrm{NH} 4 \mathrm{Cl}$ with $20 \mathrm{w} / \mathrm{o}$ of $\mathrm{Cr}-10 \mathrm{w} / \mathrm{\circ} \mathrm{Al}$ masteralloy and cyclically oxidized at $1100^{\circ} \mathrm{C}$ in static air for $5001 \mathrm{~h}$ cycles (AP arrangement).

Surface analyses by XRD and EPMA detected the $\gamma^{\prime}$ $\mathrm{Ni}_{3} \mathrm{Al}$ phase on almost all coatings after 500 cycles. In addition, $\alpha-\mathrm{Al}_{2} \mathrm{O}_{3}$ and $\mathrm{NiAl}_{2} \mathrm{O}_{4}$ spinel oxide phases were evident. Less protective surface phases such as $\gamma-\mathrm{Ni}$ and $\mathrm{TiO}_{2}$ also were detected especially on René 809 alloy substrates (Table IV).

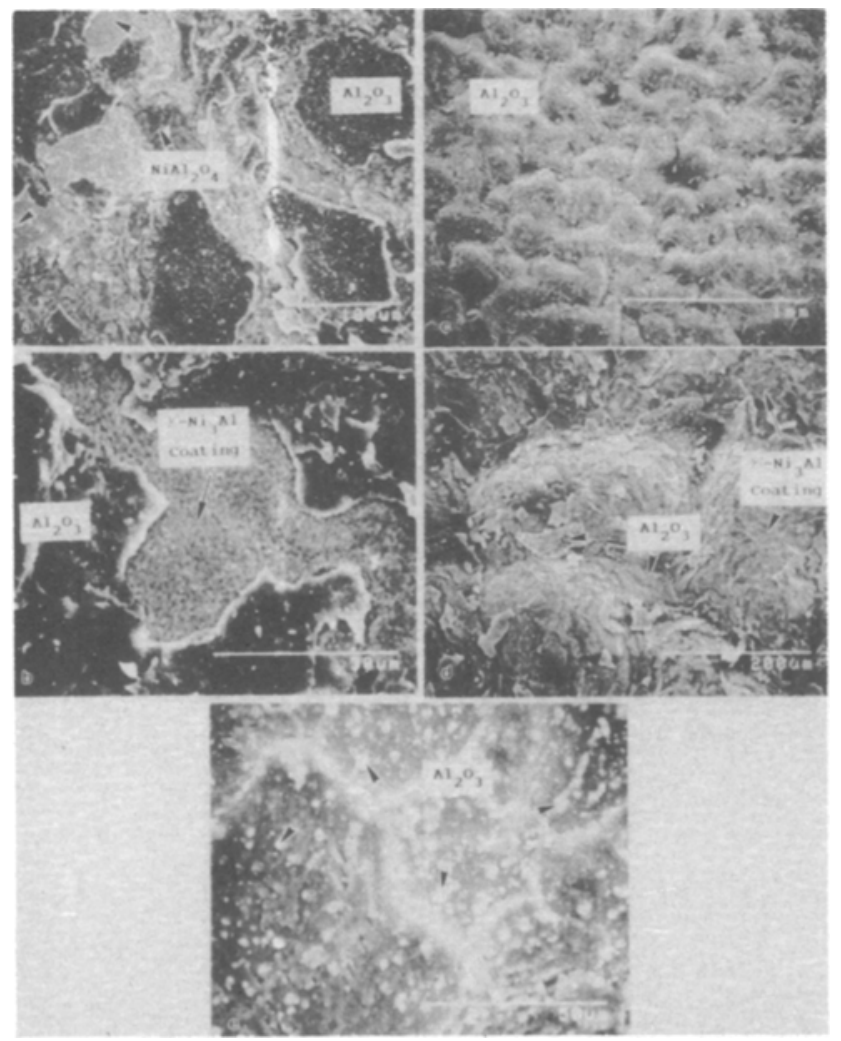

Fig. 8. Surface scanning electron micrograph of an IN 713LC alloy coated at $1150^{\circ} \mathrm{C}$ for $24 \mathrm{~h}$ in a pack containing (a, b, top) $2 \mathrm{w} / \mathrm{o}$ $\mathrm{NH}_{4} \mathrm{Cl}$ plus $2 \mathrm{w} / 0 \mathrm{Y}_{2} \mathrm{O}_{3},\left(c, d\right.$, middle) $4 \mathrm{w} / 0 \mathrm{HfCl}_{4}$, and (e, bottom) $2 \mathrm{w} / \mathrm{o} \mathrm{NH}_{4} \mathrm{Cl}$ plus $2 \mathrm{w} / \mathrm{o} \mathrm{ZrO}_{2}$ with $20 \mathrm{w} / \mathrm{o}$ of $\mathrm{Cr}-10 \mathrm{w} / \mathrm{o} \mathrm{Al}$ masteralloy and isothermally oxidized at $1100^{\circ} \mathrm{C}$ in air for $44 \mathrm{~h}$ (AP arrangement).
Representative cross-sectional backscattering electron micrographs and composition profiles (EPMA) of oxidized coatings are presented in Fig. 9-11. A 5-15 $\mu \mathrm{m}$ thick Al depleted layer $\left(\mathrm{Ni}_{3} \mathrm{Al}\right)$ was characteristic of all protective coatings, except the one shown in Fig. 9 . This one exception was an IN 713LC alloy substrate treated in a pack containing $4 \mathrm{w} / \mathrm{o} \mathrm{ZrCl}_{4}$. This coating contained an external $\beta-\mathrm{NiAl}$ layer with an inner three-phase region comprised of $\beta+\gamma^{\prime}+$ $\gamma$. Analyses with EDS detected Zr-rich internal oxides near the surface for this and other $\mathrm{Zr}$-doped aluminide coatings (Fig. 9 and 10). Such internal oxides are characteristic of $\beta$-NiAl compounds with additions of 0.2 a/o $\mathrm{Zr}$, which produced very adherent $\mathrm{Al}_{2} \mathrm{O}_{3}$ scales at $1100^{\circ} \mathrm{C} .{ }^{18} \mathrm{In}$ addition, a coarsened interdiffusion zone was observed, consisting of large refractory-rich carbides $\left(\mathrm{M}_{23} \mathrm{C}_{6}\right.$-type $)$ and sigma phase (for René 80 alloy substrates only).

Coating thickness.-To determine any effect of coating thickness, coatings were produced from packs containing $15 \mathrm{w} / \mathrm{o}$ of $\mathrm{Cr}-7.5 \mathrm{w} / \mathrm{o} \mathrm{Al}$ masteralloy powder and various activators and/or RE sources at $1150^{\circ} \mathrm{C}$ for 4 and $24 \mathrm{~h}$. These heat-treatment times produced coatings averaging 20-25 $\mu \mathrm{m}$ and 80-85 $\mu \mathrm{m}$ thick, respectively. Thicker coatings produced only limited improvements in coating lifetimes. Thinner coatings produced by the $4 \mathrm{~h}$ treatment formed adherent scales up to 200 to 300 cycles (Fig. 3). A $20-\mu \mathrm{m}$ thick, $\mathrm{Ni}_{3} \mathrm{Al}$ layer at the coating surface and a similarly coarsened interdiffusion zone again were observed for coatings oxidized for $5001 \mathrm{~h}$ cycles. At that time, the $\mathrm{Al}$ depletion zone ( $\mathrm{Ni}_{3} \mathrm{Al}$ layer) consumed almost the entire coating thickness; therefore, thicker coatings of the same composition did offer longer protection (compare Fig. 5 and 6 ). The thick coating increases the $\mathrm{Al}$ reservoir and permits more $\mathrm{Al}$ loss before the transformation to $\beta$-NiAl into the less protective, $\gamma^{\prime}-\mathrm{Ni}_{3} \mathrm{Al}$ phase. ${ }^{42}$ For both coating thicknesses, the most protective coatings, i.e., those which optimized oxide scale adherence, were produced from the same pack chemistries.

Substrate composition.-Cyclic oxidation generally was affected most by the coating composition at the surface. Aluminide coatings contain various alloying elements from the substrate which outdiffuse during the coating process. IN 713LC and René 80 alloy substrates have two major composition differences. IN $713 \mathrm{LC}$ contains no Co 


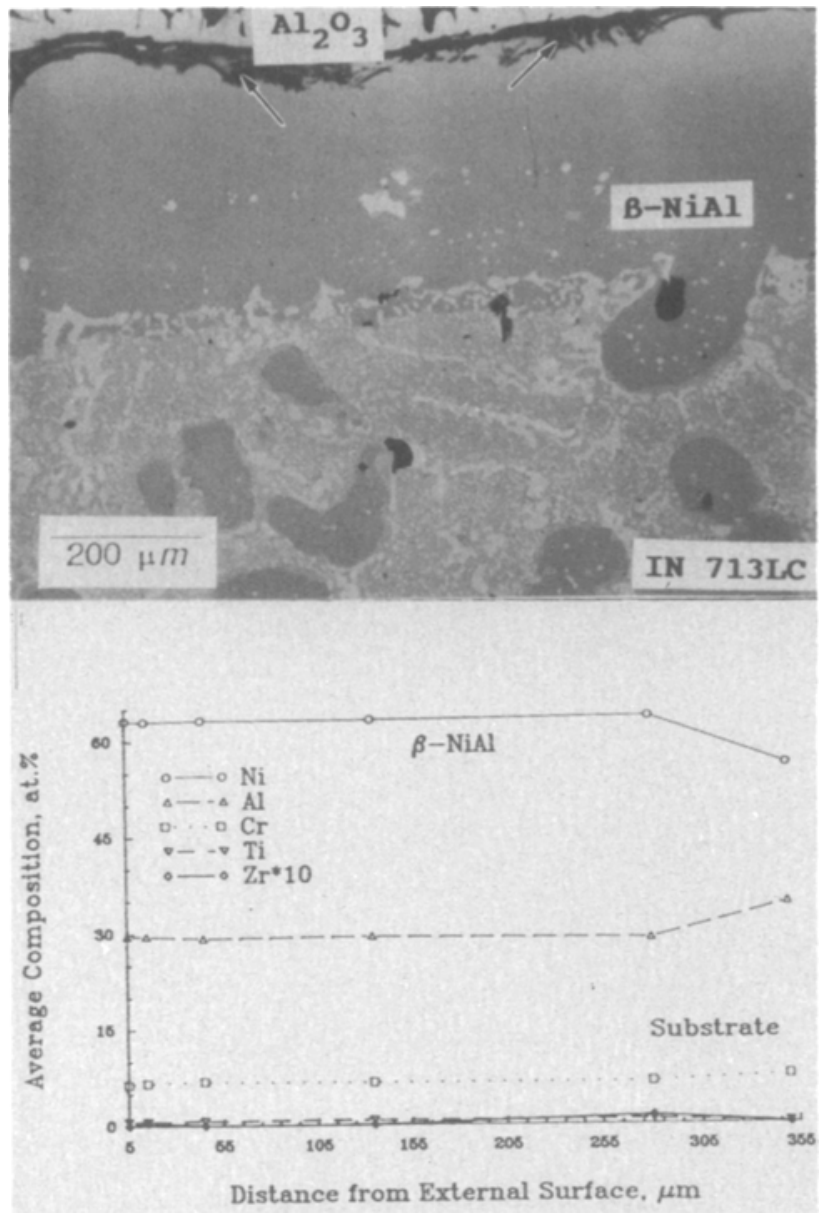

Fig. 9. Cross-sectional backscattering electron micrograph and composition profile of an IN $713 \mathrm{LC}$ alloy coated at $1150^{\circ} \mathrm{C}$ for $24 \mathrm{~h}$ in a $4 \mathrm{w} / 0 \mathrm{ZrCl}_{4}$-activated pack containing $15 \mathrm{w} / 0$ of $\mathrm{Cr}-7.5 \mathrm{w} / 0 \mathrm{Al}$ masteralloy and cyclically oxidized for $5001 \mathrm{~h}$ cycles at $1100^{\circ} \mathrm{C}$ in static air (AP arrangement).

and only $0.7 \mathrm{a} / \mathrm{o} \mathrm{Ti}$, so little transfer of Ti occurs to the coating. Aluminide coatings on René 80 alloy substrates, however, contain about 4-5 a/o Co and about 1 a/o Ti. Although small additions $(1.3 \mathrm{a} / \mathrm{o})$ of $\mathrm{Ti}$ may improve the cyclic oxidation behavior of $\beta-\mathrm{NiAl},{ }^{43}$ excessive $\mathrm{Ti}$ and $\mathrm{Co}$ levels promote the formation of less protective oxides such as $\mathrm{TiO}_{2}$ and $\mathrm{NiO}^{44}$ Uncoated IN 713LC provides better protection than uncoated René 80 during cyclic oxidation, and coated IN $713 \mathrm{LC}$ provided the best overall cyclic oxidation resistance.

Degradation mechanism.-Figure 12 is a schematic illustration of the degradation mechanism for the Cr/REmodified and RE-doped aluminide diffusion coatings. Transient oxides, including $\mathrm{Ni}(\mathrm{Al}, \mathrm{Cr})_{2} \mathrm{O}_{4}$ spinel and $\alpha-(\mathrm{Al}$, Cr) ${ }_{2} \mathrm{O}_{3}$ oxides, ${ }^{45}$ form during the initial exposure and eliminate internal oxidation by reducing the oxygen activity at the coating/scale interface. Chromium additions decrease the time of transient oxidation of $\beta-\mathrm{NiAl}$ within the 850 to $1050^{\circ} \mathrm{C}$ range by nucleating the isomorphous mixed oxide, $(\mathrm{Cr}, \mathrm{Al})_{2} \mathrm{O}_{3} .{ }^{12}$ With increasing time, the transient oxides thicken until a continuous steady-state $\alpha-\mathrm{Al}_{2} \mathrm{O}_{3}$ scale forms at the coating/scale interface, interrupting the supply of $\mathrm{Ni}$ to the transient spinel oxide. Chromium is depleted from the surface oxides by either evaporation or by spallation of the transient oxides. In addition, interdiffusion zone carbides and sigma phase (for René 80 alloy substrates) coarsen at the expense of smaller particles, $\mathrm{Cr}$ and refractory element solutes in the adjacent substrate and coating. Analysis with EPMA determined that further exposure transforms the $\mathrm{MC}$-type carbides into $\mathrm{M}_{23} \mathrm{C}_{6}$-type carbides. ${ }^{14}$ As time passes, a second interdiffusion zone containing $\mathrm{Cr}$ - and refractory-rich carbides (probably $\mathrm{M}_{23} \mathrm{C}_{6}$ and MC-type carbides) begins to form beneath the original zone because of the depletion of $\mathrm{Ni}$ and other alloying elements from the substrate. Aluminum is depleted continuously from the surface and along grain boundaries (Fig. 11) of the coating upon the formation and growth of the external $\mathrm{Al}_{2} \mathrm{O}_{3}$ protective scale. This $\mathrm{Al}$ depletion is increased substantially if the external $\mathrm{Al}_{2} \mathrm{O}_{3}$ scale spalls for every oxidation cycle. ${ }^{38}$ Aluminum depletion results in the transformation of the $\beta-\mathrm{NiAl}$ coating layer into the $\gamma^{\prime}-\mathrm{Ni}_{3} \mathrm{AI}$ phase, whereupon the formation of less protective oxide scales such as $\mathrm{NiAl}_{2} \mathrm{O}_{4}$ and $\mathrm{NiO}$ cause the end of the coating protection. ${ }^{42}$ However, microprobe analyses detected about $0.05 \mathrm{a} / \mathrm{o} \mathrm{Y}$ and $\mathrm{Zr}$ in the $\mathrm{Ni}_{3} \mathrm{Al}$ layer which, according to Taniguchi and Shibata ${ }^{37}$ and Kuenzly and Douglass, ${ }^{46}$ may be sufficient to produce adherent $\mathrm{Al}_{2} \mathrm{O}_{3}$ scales during further oxidation exposure. This explains why slow kinetics and good adherence were observed for extended times after the $\mathrm{Ni}_{3} \mathrm{~A} 1$ had formed (Fig. 6, 9, and 11).

In contrast to the $\mathrm{Cr} / \mathrm{RE}$-modified coatings, the degradation of the RE-doped aluminide coatings is controlled solely by the depletion of Al at the surface, because only limited coarsening of the interdiffusion zone was observed prior to the formation of $\mathrm{Ni}_{3} \mathrm{Al}$ following 500 cycles. Once the surface of the coating transforms to $\gamma^{\prime}-\mathrm{Ni}_{3} \mathrm{Al}(35-36 \mathrm{a} / \mathrm{o}$ $\mathrm{Al}$ at $\left.1100^{\circ} \mathrm{C}\right),{ }^{47}$ and possibly $\gamma-\mathrm{Ni}$, a protective and adherent $\mathrm{Al}_{2} \mathrm{O}_{3}$ scale cannot be sustained in cyclic oxidation, probably because of slower $\mathrm{Al}$ diffusion in the low $\mathrm{Cr} \mathrm{Ni}{ }_{3} \mathrm{Al}$ phase. ${ }^{4}$ Instead, a less protective $\mathrm{NiAl}_{2} \mathrm{O}_{4}$ spinel and $\mathrm{NiO}$ scale form. According to Fig. 4 and 7 , the presence of $\mathrm{Ni}_{3} \mathrm{Al}$, however, may not lead to immediate failure if an adherent $\mathrm{Al}_{2} \mathrm{O}_{3}$ scale is anchored to the coating by oxide pegs.

\section{Hot Corrosion (Fused-Salt Altack) Behavior}

To evaluate the resistance to high temperature (type I) hot corrosion attack (HTHCA), the $\mathrm{Cr} / \mathrm{RE}$-modified aluminide diffusion coatings were subjected to isothermal thin

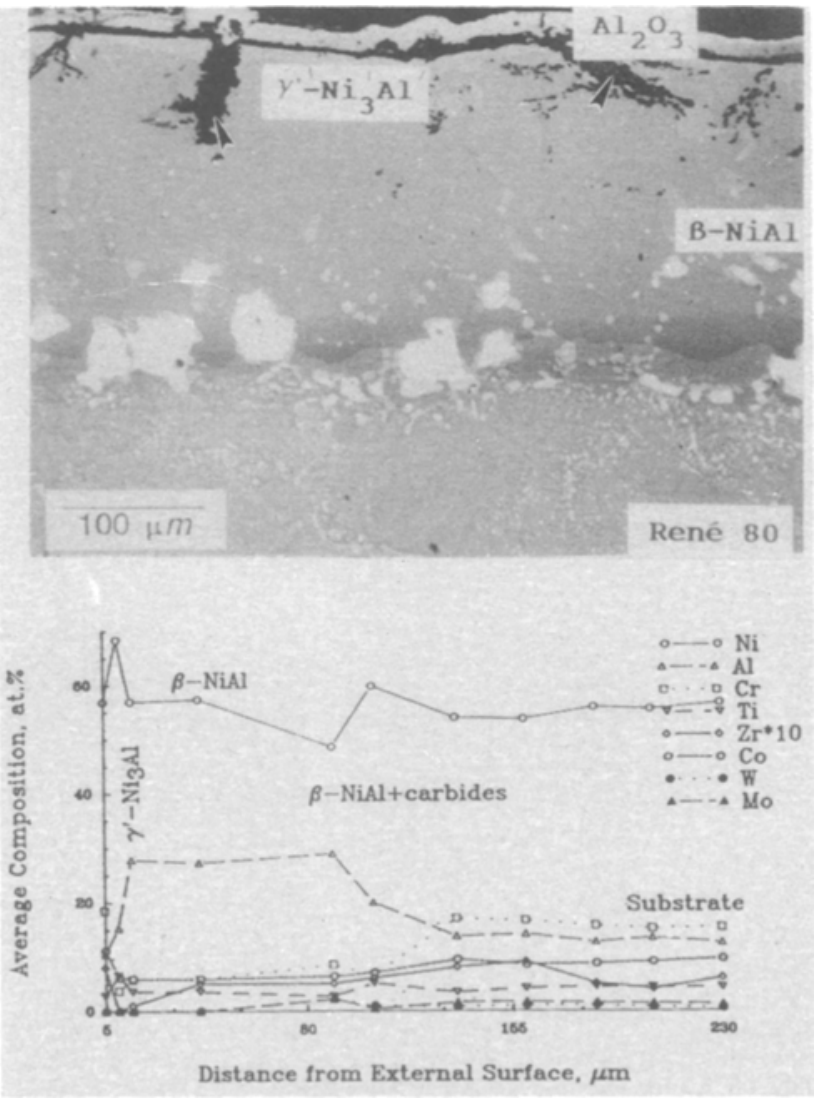

Fig. 10. Cross-sectional backscattering electron micrograph and composition profile of a René 80 alloy coated at $1150^{\circ} \mathrm{C}$ for $24 \mathrm{~h}$ in a $4 \mathrm{w} / 0 \mathrm{ZrCl}_{4}$-activated pack containing $15 \mathrm{w} / \mathrm{o}$ of $\mathrm{Cr}-7.5 \mathrm{w} / \mathrm{o} \mathrm{Al}$ masteralloy and cyclically oxidized for $5001 \mathrm{~h} \mathrm{cycles}$ at $1100^{\circ} \mathrm{C}$ in static air (ÁP arrangement). 


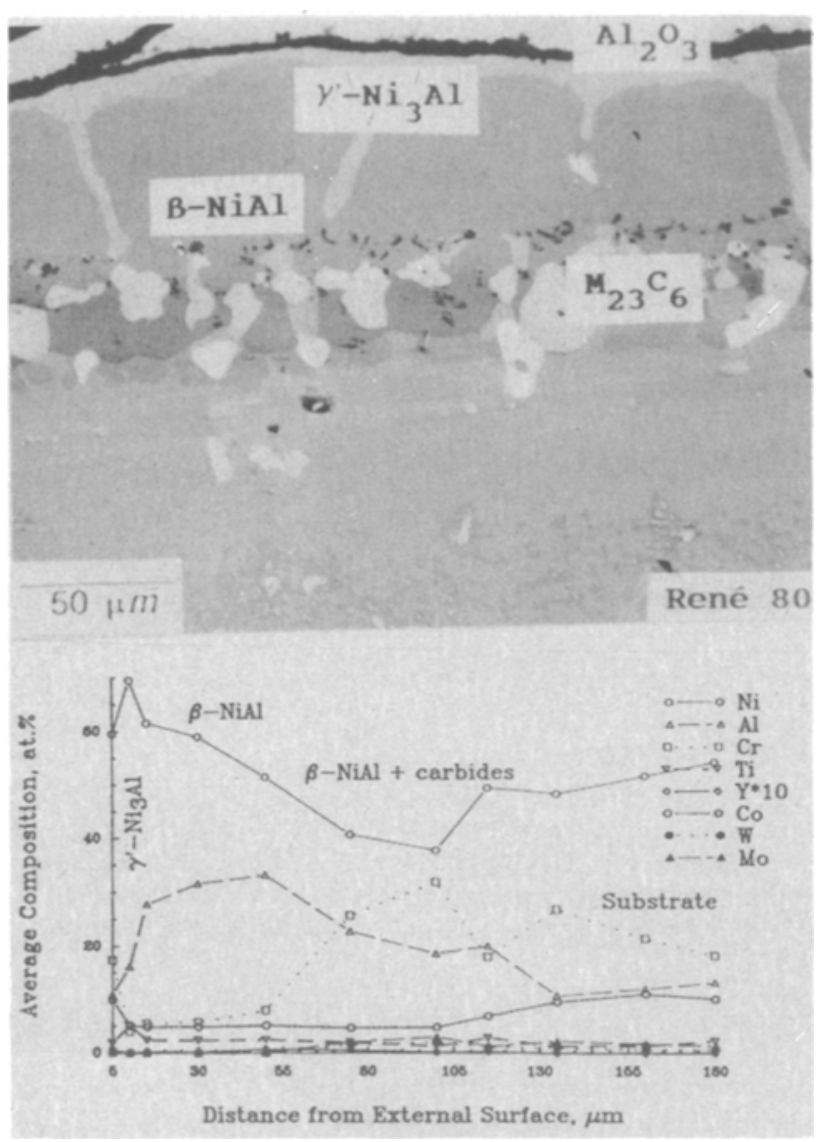

Fig. 11. Cross-sectional backscattering electron micrograph and composition profile of a René 80 alloy coated at $1150 \mathrm{C}$ for $24 \mathrm{~h}$ in a $2 \mathrm{w} / \mathrm{o} \mathrm{NH} \mathrm{Nl}_{4} \mathrm{Cl}$-activated pack containing $2 \mathrm{w} / \mathrm{o} \mathrm{Y}_{2} \mathrm{O}_{3}$ and $15 \mathrm{w} / \mathrm{o}$ of $\mathrm{Cr}-7.5 \mathrm{w} / \mathrm{O} \mathrm{Al}$ masteralloy and cyclically oxidized for $500 \mathrm{i} \mathrm{h}$ cycles at $1100^{\circ} \mathrm{C}$ in static air (AP arrangement).

film tests. X-ray diffraction results of the corrosion products are listed in Table VI and VII for alloys coated in the $\mathrm{AP}$ and in the PC arrangement, respectively. In addition, the hot corrosion performance of $\mathrm{Cr} / \mathrm{RE}$-modified aluminide diffusion coatings is presented in Table VIII. Chromium/RE-modified aluminide coatings were compared to the commercial low activity coating, GE Codep C, for the same alloy substraie. The GE Codep C process is basically an aluminizing treatment which forms an outward-grown hypostoichiometric $\beta-\mathrm{NiAl}$ coating with limited Cr enrichment $(\sim 2.2 \mathrm{a} / \mathrm{o})$ from the alloy.

Above pack arrangement.-René 80 and Mar-M247 substrates were coated in packs containing various chloride activator and $\mathrm{RE}$ sources with a suitable masteralloy composition in the AP arrangement, and only René 80 substrates were coated in a $\mathrm{PC}$ arrangement. The salted coatings $\left(5.0 \pm 1.5 \mathrm{mg} \mathrm{Na} \mathrm{SO}_{4} / \mathrm{cm}^{2}\right)$ were placed in a flowing Pt-catalyzed $0.1 \% \mathrm{SO}_{2} / \mathrm{O}_{2}$ gas mixture $\left(841 \mathrm{ppm} \mathrm{SO}_{2} / \mathrm{O}_{2}\right)$ at $900^{\circ} \mathrm{C}$. Exposed samples were quenched periodically to room temperature (e.g., following $24,72,144,240,360$, and $504 \mathrm{~h}$ ) to facilitate scale spallation. The coupons were weighed, resalted, and replaced into the furnace for up to $672 \mathrm{~h}$. The weight changes for each alloy and pack/substrate arrangement during the corrosion process are presented in Fig. 13-15. Severely corroded coupons were removed prematurely from the test as indicated by a stop of the kinetic measurements.

As shown in Table VIII, coatings from the AP arrangement failed to provide any substantial resistance to hot corrosion attack, except for one specific substrate and pack chemistry (Mar-M247 substrate coated with 2 w/o $\mathrm{NH}_{4} \mathrm{Cl}$ and 25 w/o of $\mathrm{Cr}-6$ w/o Al masteralloy). X-ray diffraction results and cross-sectional analysis of selected microstructures revealed that the original $\beta-\mathrm{NiAl}$ coating layer was
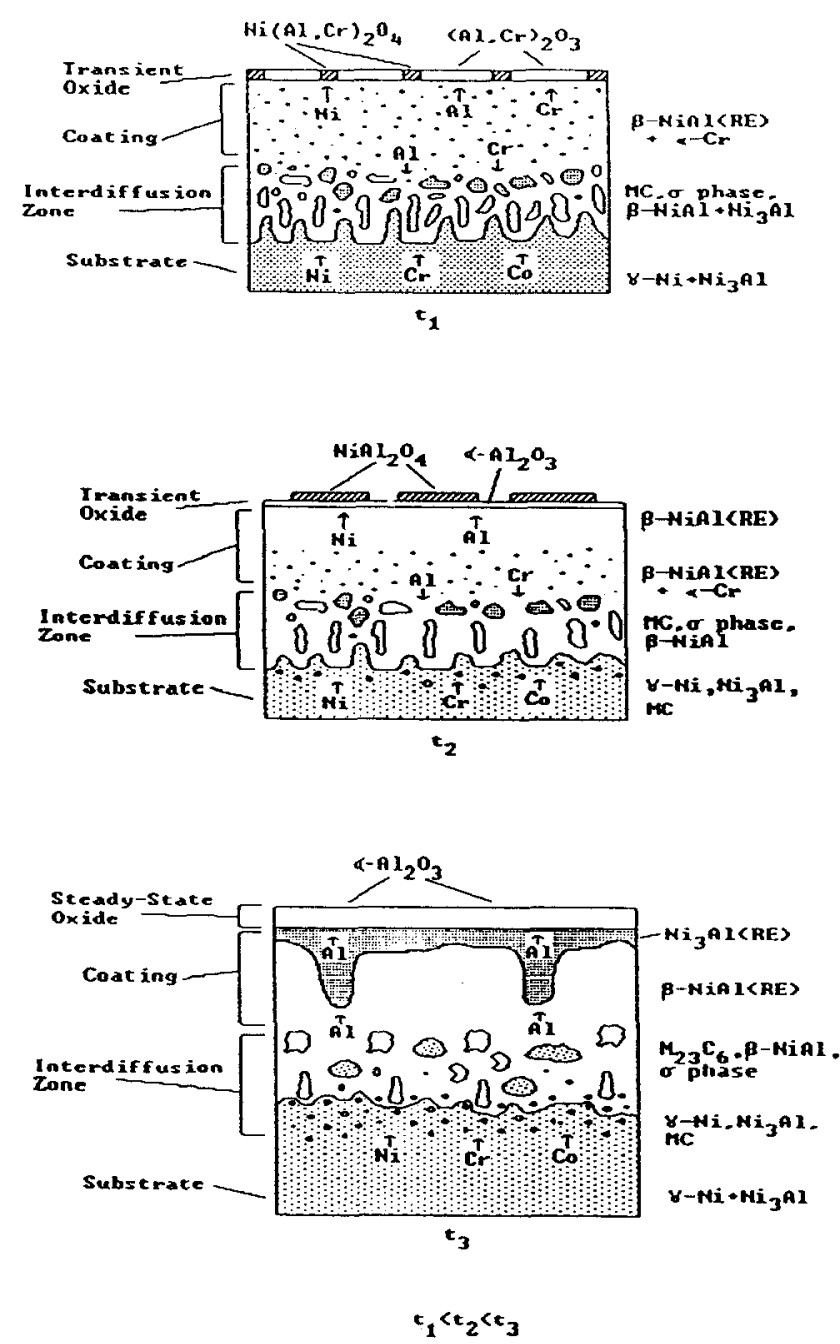

Fig. 12. Schematic illustration of the degradation mechanism of the modified aluminide diffusion coatings.

generally absent and that several unprotective external oxides and internal sulfides were present (Table VI).

The hot corrosion kinetics were characterized by an initial incubation period where a relatively protective oxide was present (Fig. 13 and 14). With time, the product scale was attacked further by the molten salt and the oxidant, exposing the coated substrate and leading to rapid weight gains. While the hot corrosion mechanism is not obvious here, continuing scale dissolution/precipitation reactions can eventually destroy the protective product scale. ${ }^{29}$ Alloy

Table VI. XRD results of René 80 and Mar-M247 alloy substrates coated at $1150^{\circ} \mathrm{C}$ for $24 \mathrm{~h}$ in a pack containing various activator salts/RE sources with $25 \%$ of $\mathrm{Cr}-6 \mathrm{w} / \mathrm{0}$ Al masteralloy and isothermally corroded at $900^{\circ} \mathrm{C}$ for $672 \mathrm{~h}$ in a Pt-catalyzed, $0.1 \% \mathrm{SO}_{2} / \mathrm{O}_{2}$ gas mixture with $5.0 \mathrm{mg} / \mathrm{cm}^{2} \mathrm{Na}_{2} \mathrm{SO}_{4}$ (AP arrangement).
Pack chemistry

René 80 $2 \% \mathrm{NH}_{4} \mathrm{Cl}$ $2 \% \mathrm{NH}_{4} \mathrm{Cl}, 2 \% \mathrm{Y}_{2} \mathrm{O}_{3}$ $4 \% \mathrm{ZrCl}_{4}$ $4 \% \mathrm{YCl}_{3}$

Mar-M247

$2 \% \mathrm{NH}_{4} \mathrm{Cl}$

$2 \% \mathrm{NH}_{4} \mathrm{Cl}, 2 \% \mathrm{Y}_{2} \mathrm{O}_{3}$ $4 \% \mathrm{ZrCl}_{4}$ $4 \% \mathrm{YCl}_{3}, \mathrm{Cr} 6 \mathrm{Al}$ $4 \% \mathrm{YCl}_{3}, \mathrm{Cr} 5 \mathrm{Al}$
XRD phases

$1,7,2,5,3,4$

$1,2,7,3,4,5$

$1,2,4,3,7,5$

$1,7,5,4,3$

$2,6,1,3,5$

$1,2,3$

$1,3,2,5$

$2,6,1,3,5$

$1,7,5,3$
Key: $1, \mathrm{NiO} ; 2, \mathrm{NiAl}_{2} \mathrm{O}_{4} ; 3, \mathrm{Ni}_{3} \mathrm{Al} ; 4, \mathrm{Ni} ; 5, \mathrm{CrS} ; 6, \mathrm{Al}_{2} \mathrm{O}_{3}$; and 7 , $\mathrm{Co}_{3} \mathrm{O}_{4}$ 
Table VII. XRD results of René 80 alloy substrates coated at $1150^{\circ} \mathrm{C}$ for $24 \mathrm{~h}$ in a pack containing various activator salts/RE sources with $25 \mathrm{w} / \mathrm{o}$ of $\mathrm{Cr}-7.5 \mathrm{w} / \mathrm{o}$ Al masteralloy and isothermally corroded at $900^{\circ} \mathrm{C}$ for 144 and $672 \mathrm{~h}$ in a Pt-catalyzed $0.1 \% \mathrm{SO}_{2} / \mathrm{O}_{2}$ gas mixture with $5.0 \mathrm{mg} / \mathrm{cm}^{2} \mathrm{Na}_{2} \mathrm{SO}_{4}$ (PC arrangement).

\begin{tabular}{lcc} 
& \multicolumn{2}{c}{ XRD results } \\
\cline { 2 - 3 } Pack chemistry & $144 \mathrm{~h}$ & $672 \mathrm{~h}$ \\
\hline $2 \% \mathrm{NH}_{4} \mathrm{Cl}$ & 1,5 & $\mathrm{a}$ \\
$2 \% \mathrm{YCl}_{3}$ & 1.5 & $1,2,5,6,4$ \\
$2 \%(2: 1) \mathrm{YCl}_{3} / \mathrm{CrCl}_{2}$ & 1,5 & $3,2,4,6$ \\
$2 \% \mathrm{ZrCl}_{4}$ & 1,5 & $\mathrm{n} / \mathrm{t}$ \\
$\mathrm{GE} \mathrm{Codep} \mathrm{C}$ & $3,6,7$ &
\end{tabular}

Key: $1, \mathrm{Al}_{2} \mathrm{O}_{3} ; 2, \mathrm{NiAl}_{2} \mathrm{O}_{4} ; 3, \mathrm{NiO}, 4, \mathrm{CrS} ; 5, \beta-\mathrm{NiAl} ; 6, \mathrm{Ni}_{3} \mathrm{Al} ; 7, \mathrm{Ni}$ a, destroyed; and $n / t$, not tested.

sulfidation can result in a large increase in the basicity of the salt film and the formation of less protective basic oxides (Table VI), which should support synergistic basic dissolution/precipitation of $\mathrm{Cr}_{2} \mathrm{O}_{3}$ and $\mathrm{Al}_{2} \mathrm{O}_{3}$ as reported by Hwang and Rapp. ${ }^{48}$ Overall coating failure is seen in Fig. 13 and 14. The general failure of these AP coatings resulted because inadequate $\mathrm{Cr}$ was enriched in the coating.

Powder contacting arrangement.-For the PC arrangement, several pack chemistries provided adequate resistance to hot corrosion attack, except for the $\mathrm{ZrCl}_{4}$-activated pack. Chromium-enriched aluminide coatings (Y-doped and undoped) were protective to at least $360 \mathrm{~h}$. This reconfirmed that $\mathrm{Cr}$ and not $\mathrm{RE}$ is the most important alloying addition to an aluminide coating or $\beta-\mathrm{NiAl}$ compound to improve the resistance to hot corrosion attack. ${ }^{32}$ The coatings produced from $\mathrm{YCl}_{3} / \mathrm{CrCl}_{2}$-activated packs survived $672 \mathrm{~h}$ with limited attack. These coatings still had detectable remnants of the original aluminide coating and formed more protective $\mathrm{Al}_{2} \mathrm{O}_{3}$ and $\mathrm{NiAl}_{2} \mathrm{O}_{4}$ oxide phases (Table VII), enriched with $\mathrm{Cr}(\sim 5-7 \mathrm{a} / \mathrm{o})$, according to EPMA analysis. The Y-doped and undoped, Cr-enriched aluminide coatings were characterized by initial linear kinetics, after which transient protective scales formed and grew with slow parabolic steady-state kinetics (Fig. 15). Substrates coated with $\mathrm{ZrCl}_{4}$-activated packs were severely corroded within the first $24 \mathrm{~h}$ of exposure, forming a thick porous scale consisting of $\mathrm{NiO}$ and $\mathrm{NiAl}_{2} \mathrm{O}_{4}$ (Table VII). This behavior was attributed to the lower $\mathrm{Cr}$ concentrations.

Cross-sectional electron micrographs and the corresponding elemental x-ray maps of the coating/corrosion product couple were made, as are presented in Fig. 16-18. Little attack of the $\beta$-NiAl coating was observed after 144 $\mathrm{h}$ of exposure for René 80 substrates coated in a pack containing $2 \mathrm{w} / \mathrm{o}$ of either $\mathrm{YCl}_{3}$ or $\mathrm{ZrCl}_{4}$ and $25 \mathrm{w} / \mathrm{O}$ of $\mathrm{Cr}-7.5$ w/o Al masteralloy, using a PC arrangement. Analyses with XRD detected a thin external $\mathrm{Al}_{2} \mathrm{O}_{3}$ scale which protected
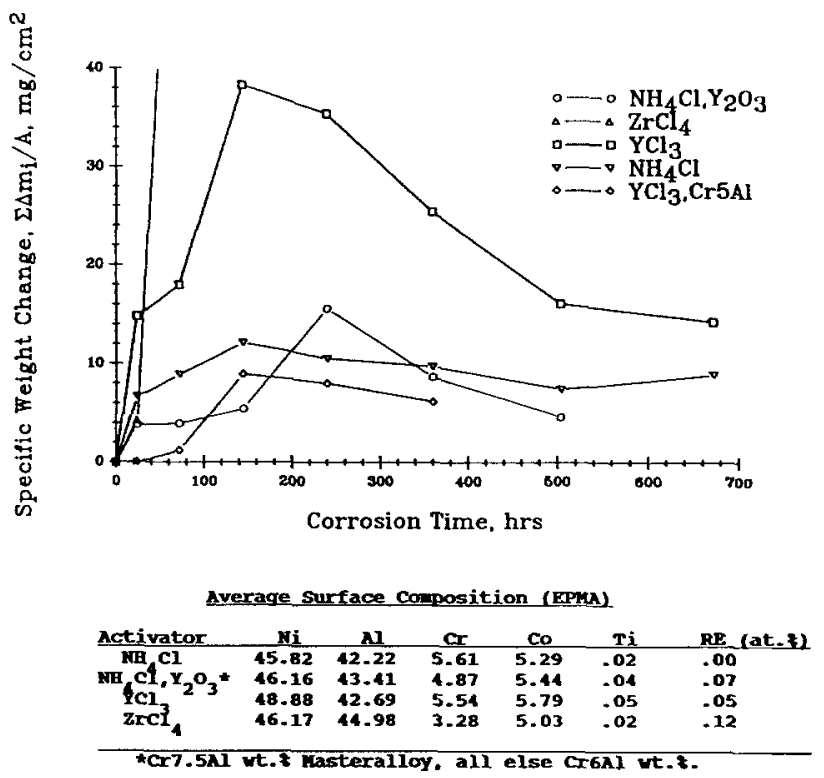

Fig. 13. Hot corrosion kinetics and average surface compositions for Mar-M247 alloys coated at $1150^{\circ} \mathrm{C}$ for $24 \mathrm{~h}$ in a pack containing various activator salts/RE sources with $25 \mathrm{w} / \mathrm{o}$ of $\mathrm{Cr}-6 \mathrm{Al}$ w/o masteralloy and isothermally corroded at $900^{\circ} \mathrm{C}$ in a Pt-catalyzed, $0.1 \%$ $\mathrm{SO}_{2} / \mathrm{O}_{2}$ gas mixture with $5.0 \mathrm{mg} / \mathrm{cm}^{2} \mathrm{Na}_{2} \mathrm{SO}_{4}$ (AP arrangement).

the coating from the molten salt (Fig. 16). Microprobe analyses did not detect any significant reduction in the $\mathrm{Cr}$ surface composition for either coating after $144 \mathrm{~h}$ of exposure, but EPMA analysis did detect a measurable amount of $\operatorname{Cr}(\sim 5-7 \mathrm{a} / \mathrm{o})$ in the surface oxide.

Significant attack was observed after $672 \mathrm{~h}$ of exposure. The surfaces of both coatings were severely pitted by the oxidation/corrosion process (Fig. 17a and 18a). For $\mathrm{YCl}_{3} /$ $\mathrm{CrCl}_{2}$-activated coatings, a thin layer of $\mathrm{Ni}_{3} \mathrm{Al}$ at the surface resulted from the gradual depletion of $\mathrm{Al}$ which occurred during the oxidation/dissolution/precipitation reactions of the corrosion process. Beneath the thin $\mathrm{Ni}_{3} \mathrm{Al}$ layer the original $\beta-\mathrm{NiAl}$ coating layer was still evident. A thick $\mathrm{Al}_{2} \mathrm{O}_{3}$ scale also was detected by WDS and XRD analyses. The interdiffusion zone consisted of coarsened carbides rich in $\mathrm{Cr}$, Mo, and W, probably $\mathrm{M}_{23} \mathrm{C}_{6}$-type carbides, and lacked any sigma phase.

For $\mathrm{ZrCl}_{4}$-activated coatings, the surface was completely transformed into a two-phase region containing $\gamma^{\prime}-\mathrm{Ni}_{3} \mathrm{Al}$ and $\gamma-\mathrm{Ni}$ with a dispersion of chromium-rich internal sulfides (indicated by arrows in Fig. 18a). A thick nonprotective $\mathrm{NiO}$ and $\mathrm{NiAl}_{2} \mathrm{O}_{4}$ scale was present, as well as a carbide-free interdiffusion zone rich in $\mathrm{Cr}, \mathrm{Co}, \mathrm{W}$, and $\mathrm{Mo}$ (probably sigma phase precipitates). For the $\mathrm{ZrCl}_{4}$ - and the $\mathrm{YCl}_{3} / \mathrm{CrCl}_{2}$-activated coatings, EPMA also indicated

Table VIII. Thin film hot corrosion results conducted at $900^{\circ} \mathrm{C}$ in a Pt-catalyzed $0.1 \% \mathrm{SO}_{2} / \mathrm{O}_{2}$ gas mixture with $5 \pm 1.5 \mathrm{mg} / \mathrm{cm}^{2} \mathrm{Na}_{2} \mathrm{SO}_{4}$.

\begin{tabular}{|c|c|c|c|c|c|}
\hline Alloy & Activator/RE source & Masteralloy & $\begin{array}{c}\text { Cr surface composition } \\
(\mathrm{a} / \mathrm{o})\end{array}$ & $\begin{array}{l}\text { Weight change } \\
\left(\mathrm{mg} / \mathrm{cm}^{2}\right)\end{array}$ & $\begin{array}{c}\text { Coating lifetime } \\
\text { (h) }\end{array}$ \\
\hline René $80^{\mathrm{a}}$ & $\mathrm{NH}_{4} \mathrm{Cl}$ & $\mathrm{Cr}-7.5 \mathrm{w} / \mathrm{o} \mathrm{Al}$ & 11.45 & 5.12 & 504 \\
\hline René $80^{a}$ & $\mathrm{ZrCl}_{4}$ & $\mathrm{Cr}-7.5 \mathrm{w} / \mathrm{o} \mathrm{Al}$ & 8.21 & 22.12 & 240 \\
\hline René $80^{\circ}$ & $\mathrm{YCl}_{3}$ & $\mathrm{Cr}-7.5 \mathrm{w} / \mathrm{o} \mathrm{Al}$ & 10.65 & 7.51 & 360 \\
\hline René $80^{a}$ & $\mathrm{YCl}_{3} / \mathrm{CrCl}_{2}$ & $\mathrm{Cr}-7.5 \mathrm{w} / \mathrm{o} \mathrm{Al}$ & 13.78 & 5.97 & 672 \\
\hline GE Codep C & $\mathrm{NH}_{4} \mathrm{Cl}$ & $\mathrm{AlC} / \mathrm{TiC}$ & 2.35 & 20.61 & 120 \\
\hline René $80^{\mathrm{b}}$ & $\mathrm{NH}_{4} \mathrm{Cl} / \mathrm{Y}_{2} \mathrm{O}_{3}$ & $\mathrm{Cr}-7.5 \mathrm{w} / \mathrm{o} \mathrm{Al}$ & 4.19 & 53.22 & 240 \\
\hline René $80^{\mathrm{b}}$ & $\mathrm{YCl}_{3}$ & $\mathrm{Cr}-6 \mathrm{w} / \mathrm{O} \mathrm{Al}$ & 4.39 & 91.03 & 72 \\
\hline René $80^{\circ}$ & $\mathrm{ZrCl}_{4}$ & $\mathrm{Cr}-6 \mathrm{w} / \mathrm{o} \mathrm{A} 1$ & 3.36 & 81.06 & 144 \\
\hline Mar-M247 & $\mathrm{NH}_{4} \mathrm{Cl} / \mathrm{Y}_{2} \mathrm{O}_{3}$ & $\mathrm{Cr}-7.5 \mathrm{w} / \mathrm{o} \mathrm{Al}$ & 4.87 & 15.65 & 504 \\
\hline Mar-M247 & $\mathrm{NH}_{4} \mathrm{Cl}$ & $\mathrm{Cr}-6 \mathrm{w} / \mathrm{o} \mathrm{Al}$ & 5.61 & 12.16 & 672 \\
\hline Mar-M247 & $\mathrm{YCl}_{3}$ & $\mathrm{Cr}-6 \mathrm{w} / \mathrm{o} \mathrm{Al}$ & 5.54 & 38.31 & 144 \\
\hline $\mathrm{Mar}-\mathrm{M} 247^{\mathrm{b}}$ & $\mathrm{ZrCl}_{4}$ & $\mathrm{Cr}-6 \mathrm{w} / \mathrm{o} \mathrm{Al}$ & 3.28 & 74.87 & 72 \\
\hline $\operatorname{Mar}-M 247^{\mathrm{b}}$ & $\mathrm{YCl}_{3}{ }^{2}$ & $\mathrm{Cr}-5 \mathrm{w} / \mathrm{o} \mathrm{Al}$ & 12.33 & 9.92 & 360 \\
\hline
\end{tabular}

\footnotetext{
PC arrangement

${ }^{\mathrm{A}} \mathrm{AP}$ arrangement.
} 


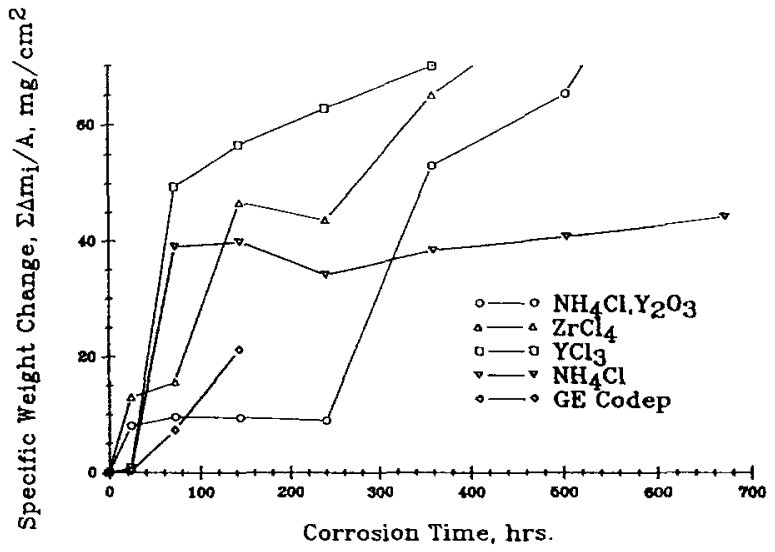

Average Surface Composition (EPMA)

\begin{tabular}{|c|c|c|c|c|c|c|}
\hline \multirow{5}{*}{$\frac{\text { Activator }}{\mathrm{KH}_{4} \mathrm{Cl}}$} & $\mathbf{N i}$ & Al & Cr. & Co & Ti & RE (at,$y)$ \\
\hline & 16.72 & 43.88 & 4.92 & 4.42 & .08 & .00 \\
\hline & 47.22 & 44.36 & 4.19 & 4.17 & .07 & .02 \\
\hline & 16.45 & 12.84 & 4.39 & 5.15 & .17 & .04 \\
\hline & 17.83 & 14.59 & 3.36 & 2.19 & .05 & -10 \\
\hline
\end{tabular}

Fig. 14. Hot corrosion kinetics and average surface compositions for René 890 alloys coated at $1150^{\circ} \mathrm{C}$ for $24 \mathrm{~h}$ in a pack containing various activator salts/RE sources with $25 \mathrm{w} / \mathrm{o}$ of $\mathrm{Cr}-6 \mathrm{w} / \mathrm{o}$ Al masteralloy and isothermally corroded at $900^{\circ} \mathrm{C}$ in a Pt-catalyzed, $0.1 \%$ $\mathrm{SO}_{2} / \mathrm{O}_{2}$ gas mixture with $5.0 \mathrm{mg} / \mathrm{cm}^{2} \mathrm{Na}_{2} \mathrm{SO}_{4}$ (AP arrangement).

significantly low $\mathrm{Cr}$ surface compositions 0.96 and $2.13 \mathrm{a} / \mathrm{o}$. These $\mathrm{Cr}$ reductions mainly resulted from the formation of internal sulfides or an external chromium-rich product scale, although no internal sulfides were detected in the $\mathrm{YCl}_{3} / \mathrm{CrCl}_{2}$-activated coatings.

Degradation mechanism.-Generally, cleaner coatings containing lower $\mathrm{Cr}$ produced in the $\mathrm{AP}$ arrangement provided less protection from fused salt attack than the packembedded PC coatings. The AP samples suffered attack similar to that of the commercial coatings produced with the GE Codep $\mathrm{C}$ process with no additional $\mathrm{Cr}$ enrichment (Fig. 15). Clearly, the overall effectiveness of aluminide coatings in type I hot corrosion is governed by the $\mathrm{Cr}$ surface composition (Table VIII). The as-deposited AP coatings consisted of two regions: an inner region comprised of $\beta-\mathrm{NiAl}$ and $\alpha-\mathrm{Cr}$, and an outer region comprised of a singlephase $\beta$-NiAl layer with limited $\mathrm{Cr}$ enrichment (e.g., 4-5 a/o) from the gas phase. Powder contacting coatings also consisted of the external $\beta-\mathrm{NiAl}+\alpha-\mathrm{Cr}$ region but with considerably more $\mathrm{Cr}$ enrichment (e.g., 8-13 a/o $\mathrm{Cr}$ ). At

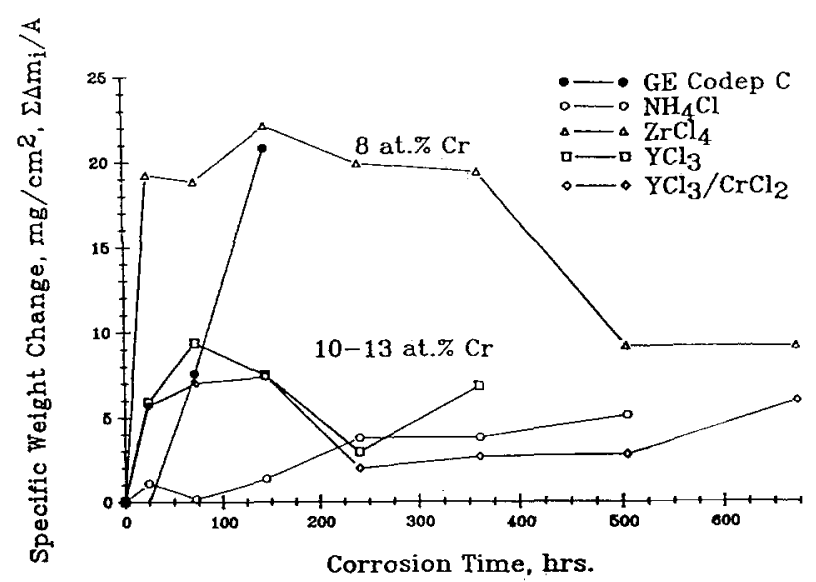

Fig. 15. Hot corrosion kinetics for René 80 alloys coated at $1150^{\circ} \mathrm{C}$ for $24 \mathrm{~h}$ in a pack containing various activator salts/RE sources with $25 \mathrm{w} / \mathrm{o}$ of $\mathrm{Cr}-7.5 \mathrm{w} / \mathrm{o}$ Al masteralloy and isothermally corroded at $900^{\circ} \mathrm{C}$ in a Pt-catalyzed, $0.1 \% \mathrm{SO}_{2} / \mathrm{O}_{2}$ gas mixture with $5.0 \mathrm{mg} / \mathrm{cm}^{2}$ $\mathrm{Na}_{2} \mathrm{SO}_{4}$ (PC arrangement).

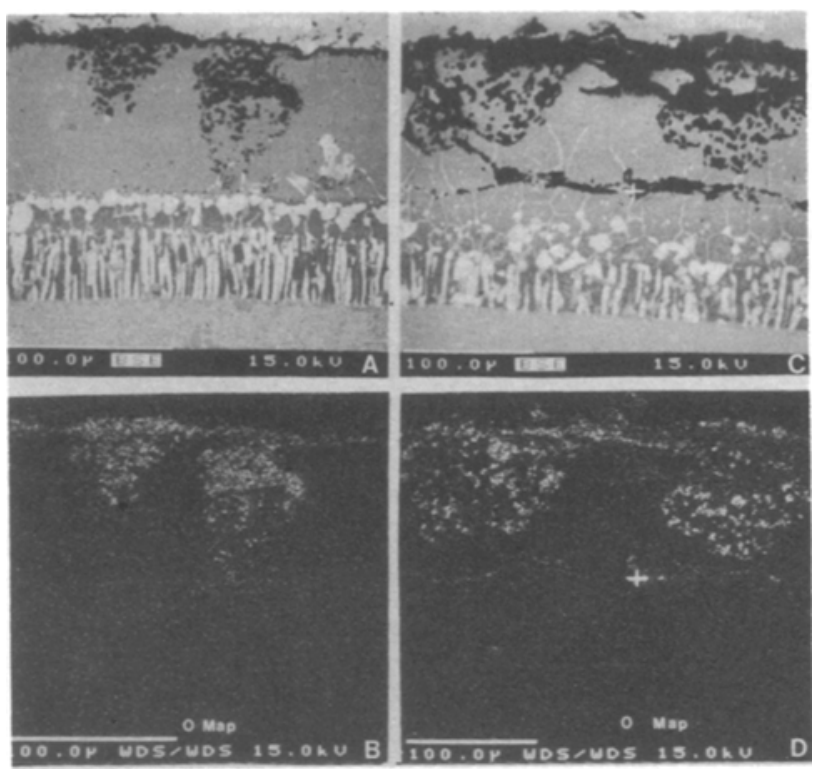

Fig. 16. (a, c) Cross-sectional backscattering electron micrograph and (b, d) corresponding oxygen x-ray map for a René 80 alloy coated at $1150^{\circ} \mathrm{C}$ for $24 \mathrm{~h}$ in a $2 \mathrm{w} / \mathrm{o}$ (a) $\mathrm{YCl}_{3}$ or (c) $\mathrm{ZrCl}_{4}$-activated pack containing $25 \mathrm{w} / \mathrm{o}$ of $\mathrm{Cr}-7.5 \mathrm{w} / \mathrm{o}$ Al masteralloy and isothermally corroded at $900^{\circ} \mathrm{C}$ for $144 \mathrm{~h}$ in a Pt-catalyzed; $0.1 \% \mathrm{SO}_{2} / \mathrm{O}_{2}$ gas mixture with $5.0 \mathrm{mg} / \mathrm{cm}^{2} \mathrm{Na}_{2} \mathrm{SO}_{4}$ (PC arrangement).

steady state, both AP and PC Cr/RE-modified aluminide coatings produced an external $\mathrm{Al}_{2} \mathrm{O}_{3}$ scale (not a $\mathrm{Cr}_{2} \mathrm{O}_{3}$ scale) during hot corrosion attack. However, EPMA analysis detected a significant amount of $\mathrm{Cr}$ within the $\mathrm{Al}_{2} \mathrm{O}_{3}$ scale for the PC coatings. Therefore, the enhanced resistance to hot corrosion attack must be attributed to this $\mathrm{Cr}$ modification of the $\mathrm{Al}_{2} \mathrm{O}_{3}$ scale.

Santoro et $a l .{ }^{39}$ have determined the oxidation behavior of $\mathrm{Ni}-(50-x) \mathrm{Al}-x \mathrm{Cr}$ alloys in air at $1100^{\circ} \mathrm{C}$ where $x=0,1,3$, or 10 a/o additions of Cr. After $100 \mathrm{~h}$ of isothermal oxidation, $\mathrm{XRD}$ analysis detected $\mathrm{Al}_{2} \mathrm{O}_{3}$ and $\mathrm{NiCr}_{2} \mathrm{O}_{4}$ spinel phases. After cyclic oxidation in static air at $1100^{\circ} \mathrm{C}$ for 100 $1 \mathrm{~h}$ cycles, no Cr-rich oxide was formed; instead, $\mathrm{Al}_{2} \mathrm{O}_{3}$ and $\mathrm{NiAl}_{2} \mathrm{O}_{4}$ spinel phases were detected. Therefore, as proposed earlier, a transient mixed oxide such as $\alpha-(\mathrm{Al}, \mathrm{Cr})_{2} \mathrm{O}_{3}$ and $\mathrm{Ni}(\mathrm{Al}, \mathrm{Cr})_{2} \mathrm{O}_{4}$ may form early upon exposure, as indicated by EPMA analysis of corroded coatings. These transient scales may provide enhanced resistance to acidic dissolution/precipitation reactions because the $\mathrm{CrO}_{4}^{2-}$ basic solute, as contrasted to the $\mathrm{AlO}_{2}^{-}$basic solute, tends to reprecipitate inward rather than outward, according to the $\mathrm{P}_{\mathrm{O}_{2}}$-dependence for $\mathrm{CrO}_{4}^{2-}$ solubility. ${ }^{49}$ At locally reducing sites such as cracks and grain boundaries, the $\mathrm{CrO}_{4}^{2-}$ solute saturates the melt and can precipitate as $\mathrm{Cr}_{2} \mathrm{O}_{3}$, thereby preventing or inhibiting salt/coating contact and sulfidation (Fig. 19). This mechanism is similar to the action of chromate inhibitors in aqueous corrosion.

Thus, $\mathrm{Cr}$-enriched aluminide coatings provide better resistance to fused salt attack compared to traditional aluminide coatings. However, as exposure continues both $\mathrm{Cr}$ and $\mathrm{Al}$ are depleted from the coating surface, either to reform or else to grow these mixed protective oxides. Eventually, a low $\mathrm{Cr}$ spinel or $\mathrm{Al}_{2} \mathrm{O}_{3}$ scale is produced, as for the traditional low $\mathrm{Cr}$ aluminide coating. According to the current investigation, a protective mixed oxide scale cannot form once the $\mathrm{Cr}$ surface composition falls below about 4 a/o (Fig. 13-15). The molten salt locally attacks this oxide scale more rapidly than the mixed oxide scale, penetrating to the underlying coating surface. The salt is then cathodically overpolarized by the metal, forming metal sulfides (e.g., $\mathrm{CrS}$ ) beneath the external surface of the coating, and further depleting $\mathrm{Cr}$ (Fig. 17). Less protective oxide scales are attacked continuously by the molten salt, exposing the underlying surface to the salt phase, depleting the surface 
of $\mathrm{Al}$, and transforming the coating surface to $\gamma^{\prime}-\mathrm{Ni}_{3} \mathrm{Al}$ and $\gamma-\mathrm{Ni}$ (Fig. 12). Finally, the coating cannot provide protection to the substrate and fails, as characterized by rapid corrosion kinetics (Fig. 13 and 14).

Since the higher Cr AP coatings show better hot corrosion resistance, but worse cyclic oxidation resistance than the cleaner low $\mathrm{Cr}$ AP coatings, further revision of the AP geometry and chemistry is needed to develop $\mathrm{Cr} / \mathrm{RE}-$ modified AP aluminide coatings with a higher $\mathrm{Cr}$ content.

\section{Conclusion}

1. In isothermal oxidation at $1100^{\circ} \mathrm{C}$ in air, $\mathrm{RE}$-doped aluminide coatings on IN 713LC substrates formed a continuous slow-growing $\alpha-\mathrm{Al}_{2} \mathrm{O}_{3}$ scale after $44 \mathrm{~h}$ of exposure. The RE-doped aluminide coatings were protected by either an outer ridged $\mathrm{Al}_{2} \mathrm{O}_{3}$ scale with an inner compact $\mathrm{Al}_{2} \mathrm{O}_{3}$ scale rich in the $\mathrm{RE}$, or by a continuous compact scale without any noticeable cracks or flaws. Conversely, RE-free aluminide coatings exhibited large fluctuations in the weight measurements, indicating periodic cracking and spalling of the oxide scale. Surface micrographs revealed a cracked oxide scale which exposed an underlying voided interface. The parabolic oxidation rate constants, $k_{\mathrm{p}}$, for the REdoped aluminide coatings were generally lower than that for RE-free aluminide coatings. The oxidation rates for the coatings agreed well with those for undoped and RE-doped. $\beta$-NiAl compounds.

2 . The cyclic oxidation behavior of $\mathrm{Cr} / \mathrm{RE}$-modified aluminide coatings on René 80 and IN 713LC alloys and of

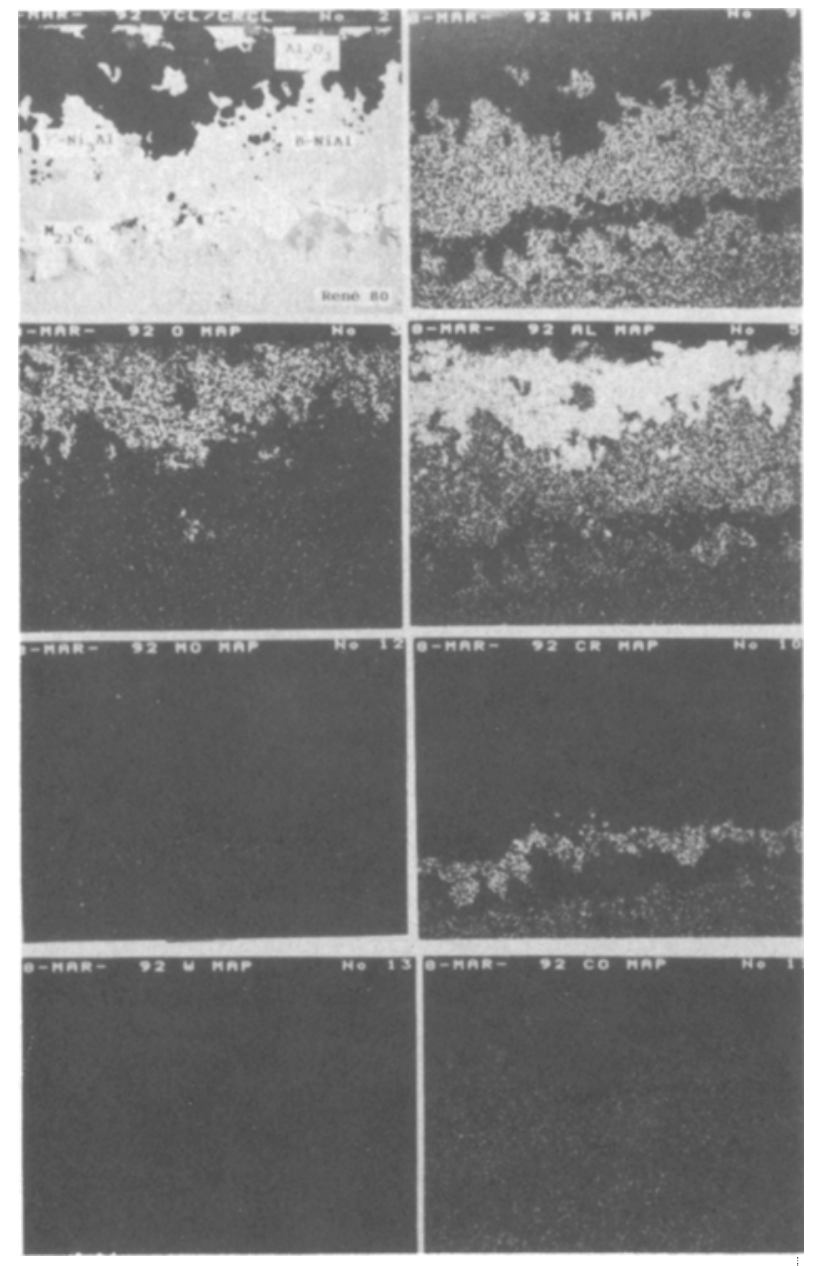

Fig. 17. Cross-sectional backscattering electron micrograph and corresponding $\mathrm{x}$-ray maps of $\mathrm{Ni}, \mathrm{Al}, \mathrm{Cr}, \mathrm{O}, \mathrm{Co}, \mathrm{W}$, and Mo for a René 80 substrate coated at $1150^{\circ} \mathrm{C}$ for $24 \mathrm{~h}$ in a $2 \mathrm{w} / \mathrm{o}(2: 1) \mathrm{YCl}_{3} / \mathrm{CrCl}_{2-}$ activated pack containing $25 \mathrm{w} / \mathrm{o}$ of $\mathrm{Cr}-7.5 \mathrm{w} / \mathrm{o}$ Al masteralloy and isothermally corroded at $900^{\circ} \mathrm{C}$ for $672 \mathrm{~h}$ in a Pt-catalyzed, $0.1 \%$ $\mathrm{SO}_{2} / \mathrm{O}_{2}$ gas mixture with $5.0 \mathrm{mg} / \mathrm{cm}^{2} \mathrm{Na}_{2} \mathrm{SO}_{4}$ (PC arrangement).
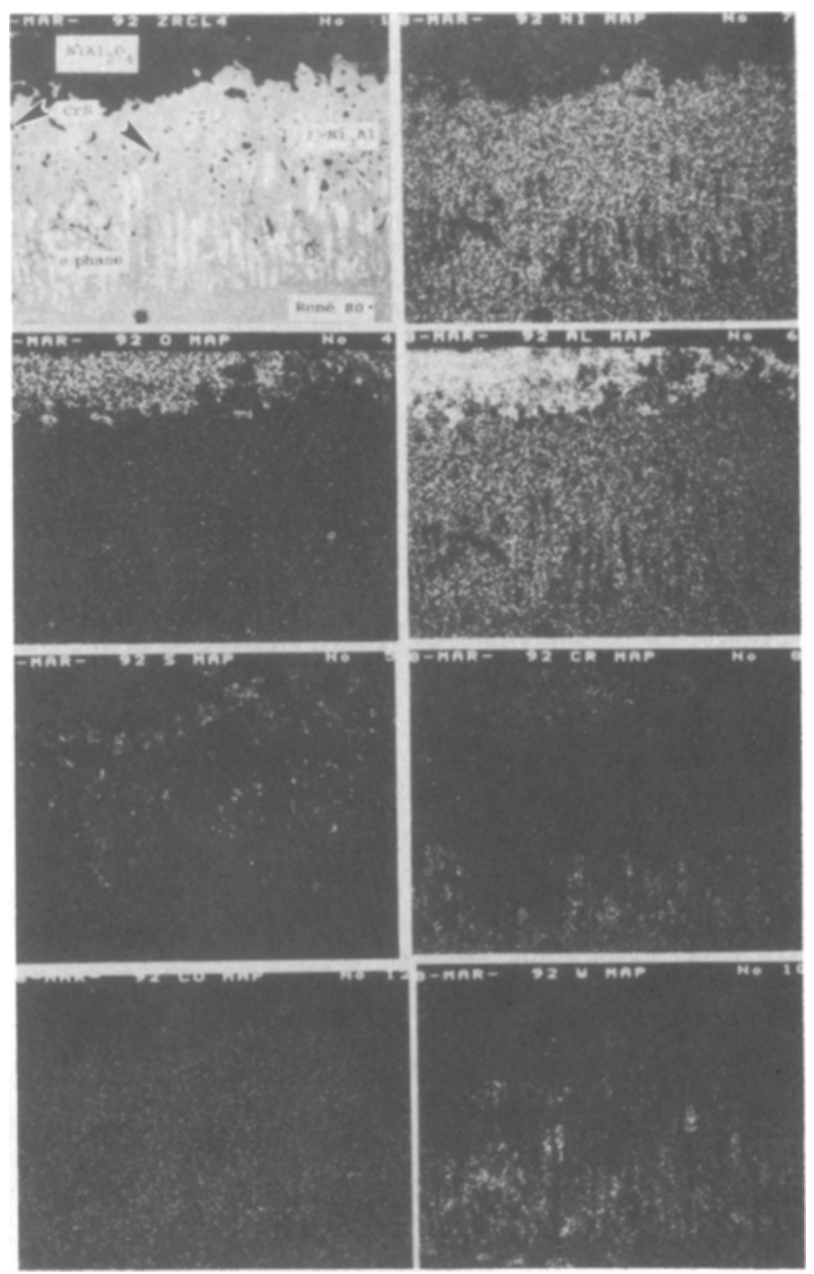

Fig. 18. Cross-sectional backscattering electron micrograph and corresponding x-ray maps of $\mathrm{Ni}, \mathrm{Al}, \mathrm{Cr}, \mathrm{O}, \mathrm{S}, \mathrm{Co}$, and $\mathrm{W}$ for a René 80 substrate coated at $1150^{\circ} \mathrm{C}$ for $24 \mathrm{~h}$ in a $2 \mathrm{w} / \circ \mathrm{ZrCl}_{4}$-activated pack containing $25 \mathrm{w} / \mathrm{o}$ of $\mathrm{Cr}-7.5 \mathrm{w} / \mathrm{o}$ Al masteralloy and isothermally corroded at $900^{\circ} \mathrm{C}$ in a Pt-catalyzed, $0.1 \% \mathrm{SO}_{2} / \mathrm{O}_{2}$ gas mixture with $5.0 \mathrm{mg} / \mathrm{cm}^{2} \mathrm{Na}_{2} \mathrm{SO}_{4}$ ( $\mathrm{PC}$ arrangement).

RE-doped aluminide coatings on IN 713LC alloys at $1100^{\circ} \mathrm{C}$ in static air was determined. Pack powder entrapment from the PC process detracted significantly from the overall cyclic oxidation performance. Coatings produced from the PC arrangement suffered severe degradation from thermal fatigue. For coatings by the AP arrangement, pack powder entrapment was eliminated, and pack chemistries were identified which provided resistance to cyclic oxidation, producing adherent $\mathrm{Al}_{2} \mathrm{O}_{3}$ scales for $5001 \mathrm{~h}$ cycles. Certain $\mathrm{RE}$-doped and $\mathrm{Cr} / \mathrm{RE}$-modified aluminide coatings

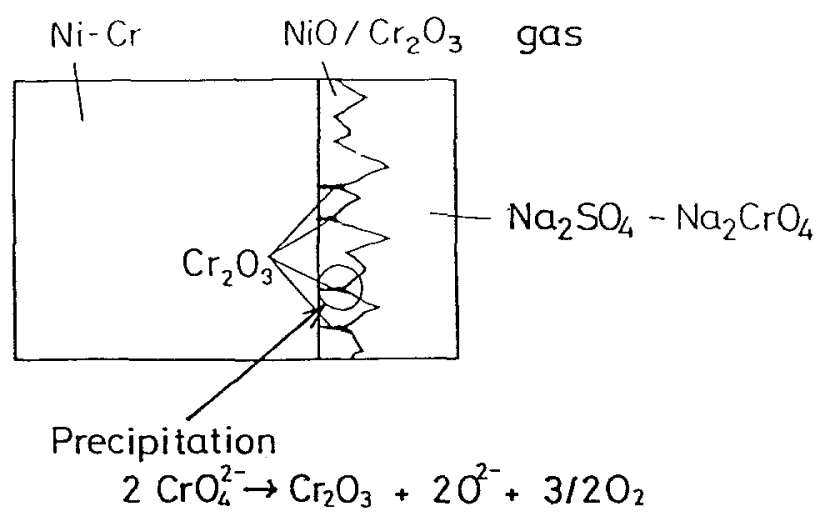

Fig. 19. Schematic representation of possible beneficial effect of chromium on hot corrosion of $\mathrm{Ni}-\mathrm{Cr}$ alloy. 
improved the adherence of protective $\mathrm{Al}_{2} \mathrm{O}_{3}$ scales considerably over undoped aluminide coatings. Chromium additions in conjunction with the RE dopant improved the resistance to cyclic oxidation attack by, presumably, increasing the diffusivity of $\mathrm{Al}$ in both the $\beta-\mathrm{NiAl}$ and $\gamma^{\prime}-$ $\mathrm{Ni}_{3} \mathrm{Al}$ phases.

3. The type I hot corrosion behavior of $\mathrm{Cr} / \mathrm{RE}$-modified aluminide coatings on René 80 and Mar-M247 alloy substrates at $900^{\circ} \mathrm{C}$ in a catalyzed $0.1 \% \mathrm{SO}_{2} / \mathrm{O}_{2}$ gas mixture was determined. The $\mathrm{Cr} / \mathrm{RE}-$ modified aluminide coatings produced from the $P C$ arrangement provided significantly better resistance to hot corrosion attack (e.g., thin film studies) than commercial low activity aluminide coatings (e.g., GE Codep C) and $\mathrm{Cr} / \mathrm{RE}$-modified aluminide coatings (of lower $\mathrm{Cr}$ content) produced by the AP arrangement. Coating lifetimes were strongly dependent on the $\mathrm{Cr}$ surface composition needed to form a mixed $(\mathrm{Al}, \mathrm{Cr})_{2} \mathrm{O}_{3}$ oxide which resists attack by the molten salt. Although the AP arrangement eliminates powder entrapment, the increased diffusion distance reduced the $\mathrm{Cr}$ flux and the resulting $\mathrm{Cr}$ surface composition. Thus, the resistance to fused salt for AP aluminides attack was decreased substantially. Further development of the AP arrangement is required to enrich more $\mathrm{Cr}$ in the coating.

\section{Acknowledgment}

The authors thank D. Little for EPMA results; C. A. McDonald for electron microscopy results; J. A. Nesbitt, C. A. Barrett, M. A. Gedwill, and D. L. Humphreys of NASA LeRC for cyclic oxidation results; R. Garlick of NASA LeRC for preliminary XRD results; and A. J. Sedriks of ONR and T. A. Kircher of NADC for funding the projects N00014-87-K-0030 and N00014-90-J-1765.

Manuscript submitted Nov. 9, 1992.

The Ohio State University assisted in meeting the publication costs of this article.

\section{REFERENCES}

1. J. W. Holmes and F. A. McClintock, Metall. Trans., 21A, 1209 (1990).

2. R. Bianco and R. A. Rapp, This Journal, 140, 1181 (1993).

3. J. L. Smialek and C. E. Lowell, ibid., 121, 800 (1974).

4. S. Shankar and L. L. Seigle, Metall. Trans., 9A, 1468 (1978).

5. F. S. Pettit, Trans. Soc. Min. Eng. AIME, 239, 1296 (1967).

6. H. M. Hindam and W. W. Smeltzer, This Journal, 127, $1630(1980)$.

7. R. Prescott, T. E. Mitchell, M. J. Graham, and J. Doychak, To be published in Proceedings of the 24th International SAMPE Technical Conference, Toronto, Oct. 1992

8. E. W. A. Young and J. H. W. de Wit, Oxid. Met., 26, 351 (1986).

9. J. Doychak, J. L. Smialek, and T. E. Mitchell, Metall. Trans., 20A, 499 (1989).

10. J. Doychak and M. Rühle, Oxid. Met., 31, 431 (1989).

11. G. C. Rybicki and J. L. Smialek, ibid., 31, 275 (1989).

12. H. J. Grabke, M. Brumm, and M. Steinhorst, Mater. Sci. Technol., 8, 339 (1992).

13. G. W. Goward, D. H. Boone, and C. S. Giggins, Trans. $A S M, 60,228$ (1967).

14. T. K. Redden, Trans. Soc. Min. Eng. AIME, 242, 1695 (1968).

15. H. C. Bhedwar, R. W. Heckel, and D. E. Laughlin, Metall. Trans., 11A, 1303 (1980).
16. J. Jedlinski and S. Mrowec, Mater. Sci. Eng., 87, 281 (1987).

17. S. Mrowec and J. Jedlinski, in Oxidation of High-Temperature Intermetallics, T. Grobstein and J. Doychak, Editors, p. 57, TMS, Warrendale, PA (1988).

18. C. A. Barrett, Oxid. Met., 30, 361 (1988).

19. J. Doychak, J. L. Smialek, and C. A. Barrett, in ibid., p. 41.

20. Private communication with J. Doychak, NASA Lewis Research Center, April 1992.

21. M. A. DeCrescente and N. S. Bornstein, Corrosion, 24, 127 (1968).

22. J. L. Luthra and O. H. LeBlanc, Jr., Mater. Sci. Eng., 87, 329 (1987).

23. J. A. Goebel, F. S. Pettit, and G. W. Goward, Metall. Trans., 4, 261 (1973).

24. N. S. Bornstein and M. A. DeCrescente, Corrosion, 26, 209 (1970).

25. D. M. Johnson, D. P. Whittle, and J. Stringer, Corros. Sci., 15, 721 (1975).

26. G. C. Fryburg, F. J. Kohl, and C. A. Stearns, This Journal, 131, 2985 (1984).

27. J. Stringer, Mater. Sci. Technol., 3, 482 (1987)

28. F. S. Pettit and C. S. Giggins, in Superalloys $I I$, C. T. Sims, N. S. Stoloff, and W. C. Hagel, Editors, p. 327, John Wiley \& Sons, New York (1987).

29. R. A. Rapp and K. S. Goto, in Proceedings of the Second International Symposium on Molten Salts, J. Braunstein and J. R. Selman, Editors, PV 81-10, p. 159, The Electrochemical Society Softbound Proceedings Series, Pennington, NJ (1981).

30. R. A. Rapp, Corrosion, 42, 568 (1986).

31. N. S. Jacobson, Oxid. Met., 31, 91 (1989).

32. R. L. McCarron, N. R. Lindblad, and D. Chatterji, Corrosion, 32, 476 (1976).

33. E. Godlewska and K. Godlewski, Oxid. Met., 22, 117 (1984).

34. B. Pieraggi, ibid., 27, 177 (1987).

35. R. Bianco and R. A. Rapp, in High Temperature Materials Chemistry-V, W. B. Johnson and R. A. Rapp, Editors, PV90-18, p. 211, The Electrochemical Society Softbound Proceedings Series, Pennington, NJ (1990).

36. C. A. Barrett, R. G. Garlick, and C. A. Lowell, NASA TM-83665 (1989).

37. S. Taniguchi and T. Shibata, Oxid. Met., 25, 201 (1986).

38. G. R. Wallwork and A. Z. Hed, ibid., 3, 229 (1971).

39. A. Steiner and K. L. Komarek, Trans. Soc. Min. Eng. AIME, 230, 786 (1964).

40. M. Ettenberg, K. L. Komarek, and E. Miller, ibid., 242, 1801 (1968).

41. W. F. Gale and J. E. King, Metall. Trans., 23A, 2657 (1992).

42. J. A. Nesbitt, E. J. Vinarcik, C. A. Barrett, and J. Doychak, Mater. Sci. Eng., A153, 561 (1992).

43. G. J. Santoro, D. L. Deadmore, and C. A. Lowell, NASA TN D-6414 (1971).

44. R. Pichoir, in High Temperature Alloys for Gas Turbines, D. Coutsouradis, P. Felix, H. Fischmeister, L. Habraken, Y. Lindblom, and M. O. Speidel, Editors, p. 191, Applied Science Publishers, Ltd., London (1978).

45. M. Brumm, Ph.D. Thesis, Universität Dortmund, Dortmund, Germany (1991).

46. J. D. Kuenzly and D. L. Douglass, Oxid. Met., 8, 139 (1974)

47. M. F. Singleton, J. L. Murray, and P. Nash, in Binary Alloy Phase Diagrams, 'T. B. Massalski, Editor, p. 141, ASM, Metals Park, OH (1986).

48. Y. S. Hwang and R. A. Rapp, This Journal, 137, 1276 (1990).

49. N. Otsuka and R. A. Rapp, ibid., 137, 53 (1990). 